\title{
Parenting Adolescents in Times of a Pandemic: Changes in Relationship Quality, Autonomy Support, and Parental Control?
}

Anne Bülow ${ }^{1,2, a}$ (bulow@essb.eur.nl), Loes Keijsers, a (keijsers@essb.eur.nl), Savannah Boele ${ }^{1,2}$ (s.boele@essb.eur.nl), Eeske van Roekel² (g.h.vanroekel@uvt.nl), \& Jaap J. A. Denissen³ (j.j.a.denissen@uu.nl)

${ }^{1}$ Department of Psychology, Education \& Child Studies/Clinical Child and Family Studies, Erasmus University Rotterdam,

${ }^{2}$ Department of Developmental Psychology, Tilburg University,

${ }^{3}$ Department of Developmental Psychology, Utrecht University

${ }^{\text {a }}$ Both contributed equally

Draft version 4, 15/4/21

This paper has been published in Developmental Psychology as:

Bülow, A., Keijsers, L., Boele, S., van Roekel, E., \& Denissen, J. J. A. (2021). Parenting adolescents in times of a pandemic: Changes in relationship quality, autonomy support, and parental control? Developmental Psychology, 57(10), 1582-1596. http://dx.doi.org/10.1037/dev0001208

(C) 2021, American Psychological Association. This paper is not the copy of record and may not exactly replicate the final, authoritative version of the article.

The published article is available on: https://doi.apa.org/fulltext/2022-06056-003.html

\section{Author Note}

The preregistered analytical plan syntaxes and data are shared on OSF (https://osf.io/bavf9/).

Funding. This research was supported by a grant from the Netherlands Organization for Scientific Research (NWO; 452-17-011) awarded to Dr. Loes Keijsers.

Acknowledgements. We are grateful for the participating families, and the support of Claire Laudijvan Koot, David Harris and Sander Vermeulen in collecting these data. 


\begin{abstract}
This Dutch multi-informant study examined effects of the first COVID-19 lockdown (e.g., school closure and social restrictions) on parent-adolescent relationships. Four bi-weekly measurements before and four bi-weekly measurements during the lockdown were collected among adolescents ( $N$ $=179, M_{\text {age }}=14.26$ years, $69 \%$ girls $)$ and their parents $\left(N=144, M_{\text {age }}=47.01\right.$ years, $81 \%$ female $)$. Parents' educational level was relatively diverse: $12 \%$ low (high school or lower), $33 \%$ medium (vocational training), 55\% high (college or university). Adolescents and parents reported on parental support, parent-adolescent conflict, autonomy support, psychological control, behavioral control, and time spent on various activities. Adolescents spent more time with their parents during lockdown (before $M=8.6 \mathrm{~h}$, during $M=12.7 \mathrm{~h}$ ), but less time with friends (before $M=8.1 \mathrm{~h}$, during $M=2.1 \mathrm{~h}$ ), and reported on average 13 COVID-19-related rules. Pre-registered piece-wise growth models confirmed that autonomy support decreased immediately during the lockdown, but no mean level changes were observed in the other relationship dimensions. During the first two months of the lockdown, parents reported gradual increases in autonomy support and decreases in behavioral control. Moreover, significant differences between families were found in sudden and more gradual relationship changes, which correlated strongly with pre-lockdown characteristics of the relationship, and in some models with adolescent oppositional defiance and legitimacy beliefs. In sum, findings suggest resilience in most families, but also heterogeneity: Some families were negatively affected and others were positively affected. A tailored approach is therefore needed to mitigate the impact of COVID-19 on family functioning.
\end{abstract}

Keywords: coronavirus, parenting, adolescents, adaptation, longitudinal 


\section{Parenting Adolescents in Times of a Pandemic: Changes in Relationship Quality, Autonomy Support, and Parental Control?}

At the time of writing this manuscript (March 2021), the 2019 coronavirus (COVID-19) has caused more than 2.6 million deaths worldwide. Over the last year, many governments took extensive preventive measures, which had a disruptive effect on the daily lives of families with children. In various countries there were periods of a societal lockdown, in which adolescents could not physically attend school, had to stay at home instead, and were discouraged from having face-toface contact with their friends. It is still largely unexplored territory how such sudden changes in the day-to-day routines of families, combined with uncertainty regarding the pandemic, may have impacted parent-adolescent relationships. Therefore, the overarching aim of this longitudinal study among Dutch families was to provide a preregistered examination to which extent parent-adolescent relationships were affected by COVID-19 lockdown measures, how families differ from each other, and which factors may explain differences in family risk and resilience.

\section{Parent-Adolescent Relationships in Adolescence}

In the larger literature on parenting adolescents (Smetana, 2017), three key dimensions of parent-adolescent relationships have been linked to adolescent well-being and positive development. That is: 1) relationship quality, including parental warmth (i.e., provision of affection, intimacy, comfort, and guidance) and parent-child conflict (i.e., quarreling, antagonism) (Furman \& Buhrmester, 1985), 2) autonomy support (i.e., promotion of volitional functioning) versus psychological control (i.e., intrusiveness, guilt induction, and love withdrawal) (Soenens et al., 2017) and (3) behavioral control (i.e., rules setting to regulate child's behavior) (Smetana, 2017). A large amount of empirical studies suggests that positive adolescent development is correlated with parentadolescent relationships characterized by 1) good relationship quality, in terms of relatively high levels of parental warmth and relatively low levels of conflicts, by 2) autonomy supportive parenting 
rather than psychological controlling parenting, and by 3) a level of behavioral control that matches with the developmental needs of the adolescent (e.g., Steinberg \& Silk, 2002).

In each of these three parent-child relationship dimensions, adolescence (age 10-24) is marked by noticeable changes, which are partially driven by an adolescent's increasing need for autonomy (Soenens et al., 2017). From middle adolescence onwards, relationships typically change from a hierarchically oriented relationship with a final say for the parent, to a more horizontal relationship in which both have an equal say (Branje, 2018; Koepke \& Denissen, 2012; Smetana et al., 2006). More specifically the level of parental behavioral control and monitoring over issues such as friendships, money, and leisure activities gradually decreases over time (Lionetti et al., 2019). However, as parents and adolescents may have different expectancies regarding what an adolescent can decide for him- or herself, the adolescent's growing demand for independence may also give rise to conflicts and a temporary dip in parental warmth in middle adolescence (Branje, 2018; De Goede et al., 2009; Laursen et al., 1998).

Although raising an adolescent may cause daily hassles and conflicts over mundane issues, the majority of families are successful in making the transition from child dependence on parents to adolescent behavioral independence and volitional functioning (Meeus, 2016; Smetana et al., 2006). Hence, most families are in a relative equilibrium of family functioning under 'normal' circumstances. The impact of the COVID-19 lockdown upon this daily equilibrium in three key dimensions of parent-child relationships (i.e., relationship quality, autonomy supportive parenting, and behavioral control), however, is unknown. In the following, theoretical arguments and first empirical indications for such an impact are briefly discussed.

\section{COVID-19 and Parent-Adolescent Relationships}

The Family Adjustment and Adaptation Response Model (FAAR Model; Patterson, 2002) integrates family stress theory with work on individual and family resilience (Masten, 2001). According to this model, the daily equilibrium of family functioning results from a balance between 
demands and capabilities. Demands include normative and non-normative stressors, and ongoing family strains (e.g., daily hassles). Capabilities include coping behaviors of the individuals and family resources, including financial means.

Most families have an adaptive capacity when they are exposed to adversities or stressors (Henry et al., 2015; Patterson, 2002), such as a sudden increase in family demands to balance work and family life, a heightened levels of uncertainty, worry, and a drastic change of daily routines due to a lockdown (Masten \& Motti-Stefanidi, 2020). The FAAR model distinguishes short-term from longer-term responses. In the short term, a temporary situation in which demands exceed capabilities may cause a disequilibrium in the daily family functioning or a crisis. However, in the longer term, the equilibrium of families can be restored, for instance by reducing demands (e.g., conflict resolution) or increasing capabilities (e.g., coping behaviors). This process is called family adaptation. Here, we define successful family adaptation as the continued ability to promote development of the individual family members in light of adversity or stress (Patterson, 1988). Finally, heterogeneity between families is likely in these short-term disequilibrium and long-term adaptation processes. Given that the COVID-19 pandemic has only recently spread across the globe, it is still an open question to which extent it has disturbed the equilibrium of family functioning, and whether or not families manage to adapt.

Governmental-imposed lockdown measures could have triggered changes in the parentadolescent relationship, as they may have increased demands and daily hassles. Novel rules installed by the government could demand that parents and adolescents renegotiate behavioral independence in domains such as personal hygiene (e.g., washing hands) or spending leisure time with peers. Whereas adolescents tend to find rules legitimate if they are well-explained and age-appropriate (Smetana \& Asquith, 1994), adolescents were now faced with sudden restrictions of their freedom, which may lead to psychological reactance and oppositional defiance (Van Petegem et al., 2015). Earlier studies in normal circumstances have shown, for instance, that prohibition of contacts with 
friends could elicit oppositional defiance among adolescents as well as parent-adolescent conflicts (Keijsers et al., 2012; Petegem et al., 2017). Hence, apart from an increase in behavioral control by parents to reinforce rules at home (e.g., not seeing friends), we expected an increase in parentadolescent conflict and a decrease in parental warmth as a result of the lockdown.

The pandemic may also cause negative feelings among parents (Achterberg et al., 2021) and adolescents (Magson et al., 2020). A recent review suggested that quarantine measures may lead to feelings of boredom and anger (Brooks et al., 2020). For adolescents, feelings of loneliness during the lockdown, in combination with the possibility that they receive less peer support because of social distancing, may place them at risk for other mental health problems such as depressive symptoms or (social) anxiety (Ellis et al., 2020; Loades et al., 2020; Marques de Miranda et al., 2020). Negative feelings in families may spill over from adolescents to parents and to the quality of their interaction (Hutchison \& Tomkunas, 2020; Van Eldik et al., 2020). Moreover, parents may experience highlighted stress levels, possibly due to a disturbance of the work-family life balance during the pandemic (Hiraoka \& Tomoda, 2020; Miller et al., 2020). Increased parental stress has been linked to daily increases in psychological control within the same family (Van Der KaapDeeder et al., 2019). Hence, we expected that parents would become less autonomy supportive and more psychologically controlling after the start of the COVID-19 lockdown measures, related to the increase in individual and family level stressors.

Indeed, the first empirical studies indicate that COVID-19 lockdown measures negatively impact family functioning - although some parents reported spending more time together as a family as something positive (Brown et al., 2020; Janssen et al., 2020). For example, parents reported more mental health problems (Achterberg et al., 2021) and difficulties with managing their children's problem behavior or their children's academic functioning during the pandemic (Brown et al., 2020). Parental mental health problems, such as depressive and anxiety symptoms, in turn, predicted higher levels of parental stress (Achterberg et al., 2021; Brown et al., 2020). The extent to which parents 
experienced stress depended on family demands, such as their financial resources (Malkawi et al., 2020) or the extent to which they experienced quarantine as difficult (Spinelli et al., 2020).

Especially parents with younger children and children with more emotional and behavioral problems experienced the COVID-19 quarantine as more difficult (Spinelli et al., 2020).

\section{Aims and Hypotheses}

Our study was based on insights into normative demands in ongoing relationship transformations from adolescent psychology, combined with the FAAR model on family stress and resilience, and the first empirical studies on COVID-19. It seemed plausible that parents' and adolescents' relatively stable patterns of daily functioning were affected in terms of three key dimensions of parent-adolescent relationships (i.e., warmth vs. conflict, autonomy support vs. psychological control, and behavioral control). Our first aim was to test mean level change in the average family with bi-weekly measurements spanning 16 weeks (4 measurements before lockdown and 4 measurements during lockdown). In comparison to pre-lockdown mean levels, we hypothesized more conflicts and less warmth (H1a), less autonomy support and more psychological control (H1b), and more behavioral control (H1c). We tested these hypotheses for adolescents and parents reports, expecting the same within-person changes for both informants. Above and beyond these more abrupt changes in family functioning (here operationalized as mean level change directly after lockdown announcement), we explored adaptation processes (here operationalized in terms of gradual changes during two months of lockdown) without a priori hypotheses.

Secondly, we investigated heterogeneity between families. Assuming some families will be more resilient to negative events and disruptions and others will be more vulnerable, we hypothesized significant differences between families in the rates of change reported by both informants (H2). We explored if these differences would be related to characteristics at the relationship level (i.e., mean level of family adjustment prior to lockdown), demands and capabilities at the individual level (i.e., trait-level parental anxiety, parental worry about COVID-19), child 
responses to changes in parenting, (i.e., oppositional defiance and legitimacy beliefs), and demographic variables (i.e., adolescent age, gender, and educational level).

Thirdly, we aimed to obtain a first understanding of the magnitude of disruptions of day-today family routines, in terms of adolescent freedom (e.g., rules, time with peers) as well as adolescents' acceptance of parental rules. Earlier studies suggest that restriction of autonomy and freedom, especially when this is considered illegitimate control by adolescents, may lead to oppositional defiance and parent-adolescent conflicts (e.g., Assadi et al., 2011; Van Petegem et al., 2015). Therefore, we hypothesized that adolescents who reported more COVID-19-related rules, compared to other adolescents, would report more oppositional defiance and more conflicts with their parents (i.e., between-person correlation - H3a). Moreover, lower levels of legitimacy beliefs were expected to be related to higher levels of oppositional defiance and more parent-adolescent conflicts (i.e., between-person correlation - H3b). As the perception of the family functioning may differ between parents and adolescents and informant differences may indicate important relational tensions (Smetana et al., 2006), we took a multi-informant approach to test all the aforementioned hypotheses.

\section{Method}

\section{Participants}

Data $\left(N_{\text {Adolescents }}=179\right.$ and $\left.N_{\text {Parents }}=144\right)$ came from a larger ongoing longitudinal study in the Netherlands, "One size does not fit all” (Boele et al., 2020). Most of these adolescents participated with a parent $(N=142), 37$ adolescents participated without a parent. Two parents participated without a child, as their child had dropped out in an earlier stage.

Adolescents were on average 14.26 years old $\left(S D_{\text {age }}=1.62\right.$, Range $=12-17$ years $)$. Most adolescents were female (69\%), born in the Netherlands (97\%), and had at least one sibling (91\%). Seventeen percent of the adolescents followed pre-vocational secondary education (VMBO), $1 \%$ a vocational/technical training $(\mathrm{MBO}), 26 \%$ higher general secondary education (HAVO), 53\% pre- 
university secondary education (VWO), and 3\% were in classes with mixed tracks (i.e., HAVO/VWO).

All participating parents were the primary caregiver (i.e., the parent with whom the adolescent spends most of the time), of which 117 were biological mothers (81\%) and 27 were biological fathers $(19 \%)$. Parents were on average 47.01 years old $\left(S D_{\text {age }}=5.19\right.$, Range $=36-76$ years). Most parents were born in the Netherlands (92\%). In terms of educational level, $12 \%$ were low-educated $(<1 \%$ did not finish high school, 11\% had high school diploma), 33\% were medium educated (vocational/technical training), and 55\% were highly educated (college or university degree). Our sample was slightly higher educated than the population of 45-55 year olds in the Netherlands (which is $20 \%$ low, $41 \%$ medium, and $39 \%$ highly educated; Central Bureau of Statistics, 2020).

\section{Procedure}

Adolescents and their parents were recruited at a large high school in the south of the Netherlands with approximately 2400 students. We informed them through information evenings for parents, newsletters, and class visits (September-November 2019). Adolescents were included if they were between 12 and 17 years old at the start of the study and encouraged to participate with at least one parent. After the inclusion of a first child, siblings were not allowed to participate, which was communicated to interested parents and adolescents. Prior to the start of the study, adolescents and parents provided active informed consent for themselves, and parents of adolescents under 16 years also provided active consent for the participation of their child. The study started in November 2019. We preregistered the original procedure before the start of the data collection (Boele et al., 2020).

Throughout the whole study, participants received online questionnaires (i.e., made in Qualtrics, 2020) by e-mail and text messages. The overall study design spanned a year, and consisted of one 'baseline' questionnaire (30-60 minutes), 26 bi-weekly questionnaires (5-10 minutes), and four 3-monthly questionnaires (10-20 minutes). Each questionnaire was sent on Sunday morning at 
10:00 AM and participants had to complete the questionnaire before next Friday 10:00 AM. Details can be found on OSF (Boele et al., 2020). Every Tuesday and Thursday morning, a reminder was sent by e-mail and text message to participants who did not yet complete the questionnaire.

Adolescents received $€ 5$ for the first 'baseline' questionnaire, $€ 2$ for the three-monthly questionnaire, and $€ 1$ for the short bi-weekly questionnaire, and they could win an additional $€ 10$ in raffles if they completed the questionnaire. Parents received $€ 0.75$ for every completed questionnaire.

In the current study, eight bi-weekly measurements waves were used, spanning 16 weeks (see Figure 1, Figure 2, and Table 1). Four assessments (January-February 2020) took place prior to the detection of the first COVID-19 patient in the Netherlands (labeled LD-4 to LD-1) and start of the lockdown (LD). One assessment took place in the week when the first COVID-19 measures were introduced by the Dutch government. This assessment was excluded because not all parents were already obliged to work from home. The four subsequent assessments, labeled LD+1 to LD+4 took place during the COVID-19 lockdown (end of March until mid-May 2020). The lockdown measures in the Netherlands consisted of keeping 1.5 meter distance, prohibition of forming a group in public (i.e., more than two people), maximum of three visitors at home, working from home, and closing of schools, catering industry and cultural facilities (e.g., museums, theaters, restaurants, bars), and leisure facilities (e.g., sports, music, art clubs, see Figure 1). Fines were $€ 390$ for adults and $€ 95$ for adolescents if they violated the rules. These measures lasted until the last measurement waves (LD+4, May, 2020). The data collection "One size does not fit all”, as well as small changes to assess the impact of COVID-19, were approved by the Ethical committee of Tilburg University nr. EC2019.65t).

\section{Measures}

\section{Parental Warmth}

Parental warmth was operationalized as parental support over the last two weeks. It was measured with a 4-item version of the Network of Relationships Inventory (NRI; Furman \& 
Buhrmester, 1985), which was translated in Dutch, shortened, and validated in earlier work (Dietvorst et al., 2018). One item was removed because of a possible high over-time stability ("How confident are you that the relationship with your mother/father will last anyway?") and to reduce burden on participants. An example item is "During the last two weeks, did your mother/father admire and respect you?" (in the online Supplemental Materials all items are provided). The items were answered on a 5-point Likert scale from "1 (not at all) to 5 (very much). Cronbach's alpha ranged from .87 to .92 for adolescent-reports, and from .75 to .83 for parent-reports.

\section{Parent-Adolescent Conflict}

To assess the frequency of conflicts between parents and adolescents in the last two weeks, we used three items from the NRI (Furman \& Buhrmester, 1985), for example: "During the last two weeks, did you and your mother/father annoy and get mad on each other?" The items were answered on a 5-point Likert scale from 1 (never) to 5 (very often). Cronbach's alpha for adolescent-reported data ranged from .85 to .90 and for parent-reported data also from .85 to .90 .

\section{Autonomy Support}

Autonomy supportive parenting was operationalized as parents' promotion of adolescents' volitional functioning. Four items with the highest factor loadings were chosen from the factor analysis presented in Soenens et al. (2007), of which three items were from the Autonomy Support Scale of the Perception of Parents Scale (POPS; Grolnick et al., 1991) and one item was from Silk et al. (2003) measure on autonomy granting (e.g., "During the last two weeks, my mother/father allowed me to decide things for myself"). The items were rated on a 5-point Likert scale from 1 (not at all) to 5 (very much). Cronbach's alpha of the scale ranged from .91 to 94 for the adolescentreported data and .92 to .93 for the parent-reported data.

\section{Psychological Control}

Psychological control was measured with the Psychological Control-Disrespect Scale (Barber et al., 2012), which measures parents' disrespect of adolescents' individuality. In terms of validity, 
the most recent version of this scale (Barber et al., 2012) showed to be a better predictor of adolescent adaptation than the older version (Barber, 1996). We used the four items with the highest factor loadings in the original study (Barber et al., 2012), for example "During the last two weeks, my mother/father did not respect me as a person (e.g., not letting me talk, favoring others over me, etc.)". We translated the items to Dutch and used a 5-point Likert response scale from 1 (never) to 5 (always). Cronbach's alpha of the scale ranged for adolescent-reported data from .85 to .91 and for parent-reported data from .67 to .78 .

\section{Behavioral Control}

Parental behavioral control was measured with three items derived from Kerr and Stattin (2000). This scale was shortened for another study based on confirmatory factor models (Keijsers et al., 2016). An example item is: "During the last two weeks, did your parents demand you to tell where you were going, with whom, and what you were going to do?” The Likert response scale ranged from 1 (never) to 5 (always). For one item about spending money, we added two answer options based on input of adolescents in focus groups: "I did not spend any money" and "my parents can always track my spending through a banking app", which we recoded as missing in this study. Cronbach's alpha was between .83 and .92 for adolescent-reported data and between .87 and .92 for parent-reported data.

\section{Time with Parents and Peers}

At the first survey during the lockdown $(\mathrm{LD}+1)$ we asked how many hours the adolescents spend with parents and friends on a 'normal' weekday and weekend-day (i.e., before lockdown) versus during the lockdown. We separately asked about face-to-face and online contact with friends. The parents answered slightly reworded questions. The scale ranged between 0 and 24 hours.

\section{COVID-19-Related Rules}

At $\mathrm{LD}+1$ we added an open question regarding new rules ("Did your parents install new rules because of the new situation with COVID-19? Briefly describe these new parental rules."). Two 
researchers grouped participants' answers into a list of 23 unique rules, including meeting no friends or meeting one friend at the time, prohibition to go outside (regularly), keeping distance, hygienerelated rules, and household chores (Table 4 contains a full overview). For instance, the answer "Don't meet with a big group of friends" and "Limit social contact" were merged under the rule: "Restrict meeting friends". At LD+2, adolescents and parents rated whether these rules applied in their household (yes or no) to obtain insights into the prevalence.

\section{Oppositional Defiance}

Oppositional defiance was measured $(\mathrm{LD}+2)$ with four items derived from the Oppositional Defiance scale of Vansteenkiste et al. (2014). An example item is: "I do exactly the opposite of what my parents expect me to do". The answer scale ranged from 1 (not at all true) to 5 (completely true). The original scale consists of eight items (Van Petegem et al., 2013) and the factor-structure of this four-item scale has been validated in two longitudinal studies (Vansteenkiste et al., 2014). The fouritem scale showed good reliability (adolescents $\alpha=.87$, parents $\alpha=.84$ ).

\section{Legitimacy Beliefs of Parental Authority}

Ten items $(\mathrm{LD}+2)$ measured adolescent legitimacy beliefs of parental authority (based on Smetana \& Asquith, 1994) concerning rules about COVID-19. Items were adapted based on the COVID-19-related rules. Highly similar rules, such as "go outside regularly", "avoid going outside", and "do not go outside" were summed up to one item. An example item is: "Given the corona-virus pandemic, it is okay that my parents installed rules about what I can or cannot do with friends". Adolescents rated these items on a 3-point scale: 1 (fully disagree), 2 (somewhat agree), and 3 (fully agree). The reliability of the scale was acceptable $(\alpha=.85)$.

\section{Parental Anxiety and Worry (about COVID-19)}

The State-Trait Anxiety Inventory Short (STAI; Marteau \& Bekker, 1992) was used to measure self-reported parental anxiety (LD+2). The scale consists of six items (e.g., "I feel tense"), which we translated to Dutch. The items were scored on a response scale from 1 (not at all) to 4 
(very much). The scale showed good reliability $(\alpha=.86)$. The short 6 -item version had a strong correlation with the full 20-item version in previous studies (Marteau \& Bekker, 1992; Van Der Bij et al., 2003). We created and added one item "I worry about COVID-19”, also scored on the same response scale.

\section{Preregistered Plan of Analysis}

We followed a preregistered plan of analysis to test our hypotheses (Bülow et al., 2021). H1 and H2 were tested using piece-wise growth models (Flora, 2008) in MPlus (Muthén \& Muthén, 2017, version 8.3). Piece-wise growth models, with additional slope factors, are specifically suited for disentangling ongoing processes of (developmental) change from change that occurs after a meaningful point in time, such as the onset of the lockdown. The model was estimated separately for each dependent variable and for each respondent (see Figure 2). The hypothesized non-linear adaptation and adjustment to COVID-19 is disentangled by modeling two distinct but overlapping linear processes. A first intercept (L1) and slope (S1) were included to model the level and linear change over the whole study period (global trend). Because factor loadings were centered around measurement LD-1 (Wainer, 2000), the first intercept can be interpreted as relationship functioning directly before the lockdown. Additionally, the first slope can be interpreted as normative (ongoing) changes in the relationship. The second intercept (L2) and slope (S2) captured changes in the level and linear slope during the lockdown, above and beyond global trends. The second intercept represents the mean level differences before versus directly after the announcement of the lockdown. It can be interpreted as a disequilibrium in the relationship at $\mathrm{LD}+1$ (providing a test of $\mathrm{H} 1$ ). The second slope captures gradual changes during to the lockdown, above and beyond normative changes. By adding a variance term to the growth factors, each trajectory of estimated growth was allowed to vary across individuals. The variance of L2 was used to test $\mathrm{H} 2$ (differences between families in abrupt change). We exported the individual slope estimates of the final model and report correlations with moderators in R (R Core Team, 2019). This approach was chosen above the 
alternative to include all moderators in the model itself, to reduce model complexity. However, this approach does not account for estimation error of the parameters.

Model fit (as indicated in Mplus) was evaluated according to preregistered criteria (two out of three criteria needed to apply: RMSEA $<.08 ;$ CFI $>.90$, TLI $>.90)$. When model fit was insufficient, models where respecified according to a preregistered stepwise approach (e.g., removing parameters to simplify the model). In addition to these growth models, Hypothesis 3 was tested by computing Pearson correlations in R (R Core Team, 2019).

\section{Missing Data}

The baseline questionnaire, including demographic measures age, gender, and educational level had no missing values. The compliance of the bi-weekly questionnaires was $83 \%$ for adolescents and $93 \%$ for parents. The pattern of missing data was analyzed using Little's MCAR Test in SPSS (preregistered inference criterion $\left.\chi^{2} / d f>5.00\right)$ (IBM Corp, 2016). Both adolescent data $\left(\chi^{2}\right.$ $\left.(d f=493)=379.57 ; p=1.00 ; \chi^{2} / d f=0.77\right)$ and parent data $\left(\chi^{2}(d f=456)=554.44 ; p=.001 ; \chi^{2} / d f=\right.$ 1.22) suggested only small deviations from the MCAR pattern. Therefore all available data were used in the analysis, using Full Information Maximum Likelihood (FIML) estimation.

\section{Results}

Table 2 shows descriptive statistics of the sample. As some children participated without a parent, and some parents without a child, explorative tests of informant differences are presented using unpaired t-tests (paired t-tests of complete dyads can be found in Table S1). In some assessments, adolescents perceived their relationship with their parent as warmer $(d=0.26-0.29)$, less conflicted $(d=0.26-0.41)$, more psychologically controlling $(d=0.26-0.31)$ and more behavioral controlling $(d=0.33-0.54)$ than their parents. No informant differences were found in autonomy support. The variables were normally distributed (skewness $<3.00$; kurtosis $<10.00$; Kline, 2011), except for one assessment of Psychological Control (LD+3, parents and adolescents).

\section{Daily Routines and Rules}


Directly after the lockdown announcement (LD+1), medium-sized to large changes occurred in the day-to-day routines of families. Both adolescents and their parents reported retrospectively to spend significantly more time together than before (see Table $3, d=.20-.67$ ). Adolescents also spent less time with their friends face-to-face $(d=.84-1.82)$, but more time with each other online or through phone than before $(d=.58)$.

All adolescents reported to have new COVID-19-related rules (Table 4 and 5 - on average 13 novel rules in adolescents' reports, 14 in parents' reports). Apart from reinforcing government guidelines at home (e.g., social distancing), rules to structure daily routines were frequently introduced (e.g., 61\% “get up on time”, 67\% “do homework”). Differences were also observed. Whereas some adolescents were urged to go outside (66\%), a small minority was mandated to stay home (4\%), and whereas some adolescents $(8 \%)$ had to restrict their time for gaming and phone use, a larger percentage of adolescents were allowed to spend more time on their phone (43\%). Regarding friends, $21 \%$ of the adolescents (vs. $29 \%$ of the parents) reported that they could not meet any friend, and $37 \%$ (vs. $63 \%$ of the parents) reported they could only meet one friend. Although parents and adolescents reported similar topics, the frequency of rules reported by parents was generally higher than adolescents' perception. Adolescents' legitimacy beliefs of the new rules was generally medium high (Table 4 and 5 - most agreed somewhat) and they reported low levels of oppositional defiance (Table 4).

\section{Changes in Parent-Adolescent Relationship Quality over Time (H1)}

According to the preregistered plan, ten piece-wise growth models were estimated (5 (Construct) x 2 (Respondent) to assess changes in parent-adolescent relationships. To control for skewness, we used the maximum likelihood for robust standard errors for the models involving Psychological Control. Nine out of 10 models had a good fit (CFI: .95-1.00, TLI: .94-1.04, RMSEA: $.00-.10-$ see Table 7), except for the model for adolescent-reported psychological control. Even after respecifying the model to reduce the model complexity, no sufficient fit could be achieved 
(intercept-only model with six measurements, RMSEA $=.09, \mathrm{CFI}=.83, \mathrm{TLI}=.86$ ). Therefore we could not test our hypothesis for this model. Sensitivity analyses were ran for two models with a sufficient fit (adolescent-reported conflict and parent-reported psychological control) to assess the impact of Heywood cases (i.e., variances of the disequilibrium parameter (L2) were negative). In these sensitivity analyses, the variances of the latent growth factors were restricted to be $>0$ (Please see Table S2), the fit remained sufficient, and the result pattern did not change. As an additional sensitivity analysis, an alternative model fit is presented in Table S3, which follows the recommendations of Widaman and Thompson (2003). The covariance-matrix of all SEM models can be found in Table S4-S13. The datasets to replicate these models can be found on OSF (Bülow et al., 2021).

We had hypothesized a disequilibrium (i.e., sudden mean level changes after the lockdown announcement) in all relationship dimensions (i.e., significant mean of L2 - Hypothesis 1). The only significant mean level change was observed for autonomy support, which was lower directly after the announcement of the lockdown, both in the adolescent-reported model $\left(M_{\mathrm{L} 2}=-0.16, p=.009, d\right.$ $=-.29)$ and the parent-reported model $\left(M_{\mathrm{L} 2}=-0.19, p=.002, d=-.48-\right.$ Figure 3$)$. Contrary to our predictions, mean level changes in the other models were not significant (see Table 7). Therefore, 7 out of 9 hypotheses regarding a mean level change were rejected. A significant gradual decline of parent-reported behavioral control $\left(M_{\mathrm{S} 2}=-0.06, p=.047\right)$ and a gradual increase in parent-reported autonomy support $\left(M_{\mathrm{S} 2}=0.10 ; p<.001\right)$ were observed in the eight weeks of the lockdown. In none of the models, an overall gradual normative trend emerged over the 16 weeks of the study (nonsignificant mean of S1).

\section{Between-Family Variances in Change (H2)}

We further hypothesized (H2) significant differences between families in the sudden mean level changes after the onset of the lockdown (significant variance of L2). Hypothesis 2 was confirmed for 4 out of 9 models (see also Figure S1), namely for parental warmth (adolescent- 
report), parent-adolescent conflict (parent-reported - Figure 4), autonomy support (adolescent-report - Figure 3), and behavioral control (parent-report). However, the effect of variance around L2 for behavioral control should be interpreted cautiously as it did not reach significance after controlling for multiple testing (see Table 7). Families also differed in the gradual change (significant variance of S2) of parental warmth (parent-report), parent-adolescent conflict (parent-report), and autonomy support (adolescent-report - Table 7).

To better understand these differences between families, we explored correlates of the relationship disequilibrium (L2) and the gradual change during lockdown (S2, presented in Table S14-S18), namely the level of family functioning before lockdown (L1), parental factors (parental anxiety and worry about COVID-19), adolescents reaction towards novel rules (oppositional defiance and legitimacy beliefs), and demographics (age, gender, and adolescent educational level).

In most relationship dimensions, pre-lockdown mean levels of functioning (L1) were associated with sudden changes after the onset of the lockdown (L2). Families with relatively higher levels of warmth decreased more strongly in warmth (adolescent report: $r(177)=-.23 p=.002$ ). Higher levels of conflict were positively associated with an increase in adolescent reported conflict $(r$ $(177)=.79 p<.001)$, but this association was negative in parent-reported conflict data $(r(142)=-$ $.45 p<.001)$. Higher baseline levels of autonomy support were associated with less pronounced decreases or stronger increases in autonomy support (parent-report: $r(142)=.35 p<.001$ ). Higher baseline levels of psychological control were associated with a stronger increase in psychological control (parent-report: $r(142)=.37 p<.001)$. Families with higher baseline levels of behavioral control, reported stronger increases in control (adolescent-report: $r(177)=.78 p<.001)$. Turning to parental factors (i.e., parental trait-level anxiety and worry about COVID-19), both were unrelated to the changes in the relationship dimensions during lockdown after controlling for pre-existing levels of family functioning. When testing associations with adolescents' reaction towards novel rules in terms of legitimacy beliefs and oppositional defiance, 4 out of 54 tests were significant after 
controlling for pre-existing levels of family functioning (see Table S14-S18), although controlling for multiple testing would make these disappear. In terms of short-term changes (L2), parents who experienced more adolescent oppositional defiance reported a steeper decrease in autonomy supportive parenting $(r(126)=-.20, p=.022)$, and stronger legitimacy beliefs as reported by adolescents correlated with an increase in parent-reported psychological control $(r(110)=.28, p=$ .003). Demographic variables were unrelated to the short-term or longer-term changes in relationship quality after controlling for the pre-existing characteristics of the relationship.

\section{Adolescents' Response to Novel Situation (H3)}

To understand adolescent responses to the lockdown, we assessed how adolescent legitimacy beliefs and oppositional defiance were correlated with parent-adolescent conflicts. As parentadolescent conflict and oppositional defiance were low and not normally distributed, we calculated non-parametric Spearman correlations (rather than Pearson correlations). Contrary to our betweenperson predictions (H3a), the number of new rules was not correlated with adolescent reports of parent-adolescent conflict $(r(138)=.06, p=.504)$ and not correlated with oppositional defiance when correcting for multiple testing for two informants $(r(138)=-.17, p=.044)$. For parent reports, new rules were not correlated with parent-adolescent conflict $(r(127)=-.03, p=.713)$ nor with oppositional defiance $(r(127)=-.06, p=.514)$. Adolescent legitimacy beliefs were not correlated with parent-adolescent conflict $(r(138)=-.09, p=.279)$, but negatively correlated with oppositional defiance $(r(138)=-.22 p=.010)$, as expected $(\mathrm{H} 3 \mathrm{~b})$. That is, adolescents who thought it was more legitimate that their parents installed novel rules regarding COVID-19, compared to others, were less oppositional than others.

\section{Discussion}

According to theories on family resilience (Henry et al., 2015; Patterson, 2002), the equilibrium of daily functioning in families may get disturbed when situational demands outweigh the family's resources and capabilities. As the COVID-19 pandemic could affect the family system 
(Masten \& Motti-Stefanidi, 2020), this multi-informant 8-wave study among Dutch families examined its impact on three key dimensions of parent-adolescent relationships: parental warmth (vs. conflict), autonomy support (vs. psychological control), and behavioral control. Findings demonstrated that the daily routines of families with adolescents changed quite strongly during the lockdown, with youths spending more time with their parents and less time with friends. Moreover, an average of 13 new family rules were installed directly after the announcement of the lockdown (e.g., not seeing friends). The impact on the parent-adolescent relationship was modest at best, however. Most adolescents seemed to think that these novel rules were legitimate. In terms of relationship changes, although parents became less autonomy supportive at the beginning of the lockdown, this recovered according to parents (but not their children) two months into the lockdown. For the other dimensions of parent-adolescent relationships, disruptions of day-to-day routines did not have sufficient magnitude to disrupt the dynamic equilibrium in the average family, counter to our expectations.

However, we also found that small effects at the aggregate level may have masked heterogeneity between families: Whereas some parent-adolescent relationships seem to have benefitted from the changes in their daily life (e.g., more warmth, less conflict), other families may have faced poorer family functioning (e.g., less warmth, more conflict) (Janssen et al., 2020). The pre-existing characteristics of the relationships, and to a lesser extent adolescents' legitimacy beliefs and oppositional defiance, partially explained these divergent response patterns. Neither parental trait-level anxiety or COVID-19-related worry, nor demographic variables were related to these differences. Below, we discuss these findings in light of the study's limitations, and provide potential practical implications.

\section{Family Disequilibrium and Adaptation During Lockdown}

In this study we tested more immediate changes in the daily routines and family functioning during lockdown as well as possible adaptation processes over two months in three key dimensions 
of parent-adolescent relationships. As primary socialization agents, parents play a fundamentally important role in teaching and monitoring behaviors of their adolescents. One of the stronger changes in family routines was the introduction of more than a dozen novel rules by parents (e.g., restrictions to see friends, getting up on time, washing hands). These rules reduced adolescents' freedom to decide on issues in quite personal domains, such as hygiene and friendships (Smetana \& Asquith, 1994), and may as such impact the equilibrium of parent-adolescent relationships. Consistent with this, longitudinal models indeed revealed a decrease in autonomy supportive parenting according to adolescents $(d=-.29)$ and parents $(d=-.48)$. Although these effects observed over four weeks were only small to medium-sized, the magnitude was similar to longitudinal studies that assess changes over several years of development (De Goede et al., 2009). Our findings also provided some evidence for the adaptive capacity of families described in resilience literature (e.g., Masten \& Motti-Stefanidi, 2020): In the two months of the lockdown, parents reported that their level of autonomy support had been restored (but this could not be detected in the adolescent report).

As adolescents' increasing need for autonomy is a driving force in relationship transformations and conflicts may emerge over decision making, we had expected that a reduction of freedom would affect the parent-adolescent relationship. However, counter to our expectations, levels of warmth, conflict, behavioral control, and psychological control did not suddenly change during the lockdown (see also, Janssen et al., 2020). Apart from the short time frame of observation, one potential explanation for this small impact lies in adolescents' legitimacy beliefs.

Conflicts may emerge over issues that are multifaceted (Smetana \& Asquith, 1994). For instance, adolescents may find friendships a personal choice and may respond with oppositional defiance when parents try to protect their adolescents from hanging around with certain peers (Keijsers et al., 2012). Indeed, we also observed informant differences: Adolescents perceived the relationship as warmer, less conflicted, but also more psychologically and behaviorally controlling than their parents. However, on many other aspects, parents and children seemed to agree. No 
informant differences were found in autonomy support. In terms of COVID-19 induced change, both adolescents and parents reported declines in autonomy support, although directly comparing the adolescent- and parent-models was hindered by incomplete dyads.

Moreover, $29 \%$ of the parents prohibited face-to-face contact with friends to ensure social distancing, yet $49 \%$ of the adolescents thought it was okay that parents interfered. This suggests that most parents and adolescents in this Dutch sample agreed that not seeing friends in times of COVID19 may actually be prudential, and adolescents may therefore be quite accepting of these novel rules, although we did not assess whether or not they obeyed the rules (Darling et al., 2008). Relatedly, levels of oppositional defiance and parent-adolescent conflicts were low in this study. Moreover, results indicate that adolescents have compensated missing their friends to some extent by an increase in social media use (from 3 hours normally, to 6 hours during the lockdown). In sum, in the average Dutch family, the impact of COVID-19 on parent-adolescent relationships was threefold: 1) a strong change in time spent together at the cost of spending time with friends, 2) more than a dozen novel rules, and 3) a sudden drop in experienced and provided autonomy support.

\section{Heterogeneity Between Families}

Most modern theories on parent-child relationships acknowledge that each family is an unique dynamic system. When situational demands suddenly change, as is the case with lockdown measures, this may lead to daily hassles and stress in some families, but it may also provide opportunities for others. As predicted by the FAAR model (Patterson, 2002), significant heterogeneity was found in terms of changes in relationship quality. Findings suggest that whereas for some families the parent-adolescent relationship improved during the lockdown, for other families the parent-adolescent relationship deteriorated.

To foster family resilience in times of increased daily hassles or family risk, and to understand why this heterogeneity emerges, multiple levels of the system need to be studied to assess short-term and longer-term adaptation processes (Henry et al., 2015; Masten \& Motti-Stefanidi, 
2020). Therefore, we assessed whether demographics, and the more proximally related relationship qualities, parental factors, and child factors could explain the impact of the COVID-19 measures on the relationship.

Most strongly, families with higher baseline mean levels of autonomy supportive parenting, psychological control, and behavioral control, became more autonomy supporting, more psychologically controlling, and more behaviorally controlling, respectively, directly after the onset of the lockdown. Such divergent change trajectories depending on earlier levels of functioning have also been reported under normal circumstances (Laursen et al., 2010): oftentimes, the poor get poorer and the rich get richer.

To a lesser extent, adolescents' responses to the novel day-to-day situation during lockdown might explain some of the differences between families. Indeed, adolescents who felt that parental rules were less legitimate also reported more oppositional defiance than other adolescents, which may lead to an additional demand on the family system as a whole. However, one limitation was that adolescents' reaction towards the novel situation was assessed three weeks after the lockdown. With regard to parental factors, earlier literature suggests that parental levels of stress may affect parenting practices (e.g., Van Der Kaap-Deeder et al., 2019), which was not supported in this study after taking earlier levels of psychological control into account.

Eight weeks into the lockdown, the first signs of the adaptive capacity of families were observed, and this flexibility to adapt also differed from family to family. Although this is just a relatively short time window, small effects could possibly accumulate and grow over time, both for better and worse (Masten \& Motti-Stefanidi, 2020). Family demands may pile up over time as the pandemic endures (e.g., due to job loss and financial concerns) and stress of parents may directly undermine their capacity to support adolescents' autonomy development (e.g., Van Der Kaap-Deeder et al., 2019). The extent to which sudden changes may have impacted the developmental trajectory of 
family functioning, or whether families bounce back or even flourish in the 'new normal' is still an open question.

\section{Practical Implications}

As the pandemic will probably endure or new pandemics may arise, studies like these on the impact of the first lockdown may help to find resources of resilience and promising targets for supporting families with adolescents. After an initial decrease in autonomy supportive parenting, parents managed to increase their autonomy support again despite enduring societal restrictions. This flexibility to adjust can be considered a sign of family adaptation (Patterson, 1988) and may serve as an important family resource to navigate challenges, stress, and increasing uncertainty when the pandemic endures. For instance, it has been suggested that parents may use adversity as an opportunity to teach adolescents how to regulate negative emotions and how to cope with stress (Henry et al., 2015). Autonomy supportive parenting in particular may help adolescents to regulate heightened negative emotions during COVID-19 and may as such serve as a protective factor against adolescent internalizing problems (Brenning et al., 2015).

At the same time, by demonstrating large heterogeneity between families, this study suggests that protective resources are more readily mobilized in families who were already better functioning. On the other end of the spectrum, there was a meaningful subset of families in which parentadolescent conflicts and psychological control increased. Specific worries have been expressed regarding families who are more vulnerable, for instance due to poverty, divorce, or parent's or children's psychopathology, or somatic diseases (Malkawi et al., 2020; Masten \& Motti-Stefanidi, 2020). COVID-19 may cause significant stress and developmental risk for them, especially considering reports that the youth care system might be struggling to provide sufficient professional support (Clemens et al., 2020). Hence societal investments in alternative manners to teach adolescents how to cope with stress and negative emotions, without requiring face-to-face contact or home visits, such as eHealth, is therefore needed and opportune. 


\section{Limitations}

Although the study employed a preregistered analysis plan and 8-wave longitudinal design with multiple informants covering periods before and during lockdown, the findings need to be interpreted in light of several limitations. Relatively higher-educated and well-functioning families were overrepresented in this study. Future research is needed in more diverse samples including families who are already at risk or are from a different cultural background.

There are also several methodological limitations. First, some items may not have applied to each child during the lockdown, such as the items of behavioral control (e.g., "Before you left on the weekend, did your parents demand you to tell them where you were going and with whom?”). Therefore, results concerning behavioral control should be interpreted cautiously. Second, time spent with parents and peers before the lockdown was retrospectively asked during the COVID-19 lockdown, and hence, responses could be biased. Third, we have to carefully reflect on the number of null-hypotheses significance tests that were carried out. Especially exploring several moderators of relationship change let to 162 significance tests, which could have led to several false positive findings. Consequently, these results should be interpreted cautiously.

Finally, it is still an open question if, and how, COVID-19 may affect family functioning beyond the here studied time window. One the one hand, it may have been that the more immediate processes of disequilibrium (e.g., conflicts over novel rules) had already been resolved at the first post lockdown assessment. Assessing short-term fluctuations within families and short-term mechanisms that cause change calls for a different type of study design, such as daily diaries or Experience Sampling Methods (Boele et al., 2019; Janssen et al., 2020). On the other hand, it might be that there is a long-term impact, so more research is urgently needed. Especially in already vulnerable families, stress and vulnerabilities may pile up, spread across developmental domains, and trigger a trajectory of family malfunctioning (Patterson, 2002).

\section{Conclusion}


This study examined whether parent-adolescent relationships were affected by COVID-19 lockdown measures, by studying abrupt and more gradual changes in three key domains of parentadolescent relationships. The day-to-day routines of Dutch families changed quite strongly in terms of hours spent together and with friends. Directly after the onset of the lockdown, parents also became less autonomy supportive. Autonomy support was adapted to the new situation in the two months thereafter, allowing more adolescent volitional functioning despite the endurance of the lockdown. Whereas some parent-adolescent relationships seemed to have benefitted from spending more time together, other families seemed to be struggling, resulting in poorer family functioning. Although there were between-family differences in the worry parents expressed and adolescents' acceptance of the novel situation, only the pre-existing characteristics of the relationship and to a lesser extent adolescent legitimacy beliefs and oppositional defiance could explain some of the divergent patterns of relationship change. 


\section{References}

Achterberg, M., Dobbelaar, S., Boer, O. D., \& Crone, E. (2021). Perceived stress as mediator for longitudinal effects of the COVID-19 lockdown on wellbeing of parents and children. Scientific Reports. https://doi.org/10.31234/OSF.IO/PJ3SG

Assadi, S. M., Smetana, J., Shahmansouri, N., \& Mohammadi, M. (2011). Beliefs about parental authority , parenting styles , and parent - adolescent conflict among Iranian mothers of middle adolescents. International Journal of Behavioral Development, 35(5), 424-431. https://doi.org/10.1177/0165025411409121

Barber, B. K. (1996). Parental Psychological Control : Revisiting a Neglected Construct. Child Development, 67(6), 3296-3319.

Barber, B. K., Xia, M., Olsen, J. A., McNeely, C. A., \& Bose, K. (2012). Feeling disrespected by parents: Refining the measurement and understanding of psychological control. Journal of Adolescence, 35(2), 273-287. https://doi.org/10.1016/j.adolescence.2011.10.010

Boele, S., Denissen, J., Moopen, N., \& Keijsers, L. (2019). Over-time Fluctuations in Parenting and Adolescent Adaptation Within Families: A Systematic Review. Adolescent Research Review. https://doi.org/10.1007/s40894-019-00127-9

Boele, S., Keijsers, L., \& Bülow, A. (2020). One size does not fit all. OSF. https://osf.io/e2jzk/

Branje, S. J. T. (2018). Development of parent-adolescent relationships: Conflict interactions as a mechanism of change. Child Development Perspectives, 12, 171-176. https://doi.org/10.1111/cdep.12278

Brenning, K., Soenens, B., Petegem, S. Van, \& Vansteenkiste, M. (2015). Perceived Maternal Autonomy Support and Early Adolescent Emotion Regulation: A Longitudinal Study. https://doi.org/10.1111/sode.12107

Brooks, S. K., Webster, R. K., Smith, L. E., Woodland, L., Wessely, S., Greenberg, N., \& Rubin, G. J. (2020). The psychological impact of quarantine and how to reduce it: rapid review of the 
evidence. The Lancet, 395(10227), 912-920. https://doi.org/10.1016/S0140-6736(20)30460-8

Brown, S. M., Doom, J. R., Lechuga-Peña, S., Watamura, S. E., \& Koppels, T. (2020). Stress and parenting during the global COVID-19 pandemic. Child Abuse and Neglect, Advanced online publication. https://doi.org/10.1016/j.chiabu.2020.104699

Bülow, A., Keijsers, L., Boele, S., Van Roekel, E., \& Denissen, J. J. A. (2021). Parenting Adolescents in Times of a Pandemic: Changes in Relationship Quality, Autonomy Support, and Parental Control? - Preregistatrion, Syntax \& Data. OSF. https://osf.io/bavf9/

Central Bureau of Statistics. (2020). Bevolking; hoogstbehaald onderwijsniveau en onderwijsrichting. https://opendata.cbs.nl/

Clemens, V., Deschamps, P., Fegert, J. M., Anagnostopoulos, D., Bailey, S., Doyle, M., Eliez, S., Hansen, A. S., Hebebrand, J., Hillegers, M., Jacobs, B., Karwautz, A., Kiss, E., Kotsis, K., Kumperscak, H. G., Pejovic-Milovancevic, M., Christensen, A. M. R., Raynaud, J. P., Westerinen, H., \& Visnapuu-Bernadt, P. (2020). Potential effects of "social" distancing measures and school lockdown on child and adolescent mental health. European Child and Adolescent Psychiatry, 29(6), 739-742. https://doi.org/10.1007/s00787-020-01549-w

Darling, N., Cumsille, P., \& Martínez, M. L. (2008). Individual differences in adolescents' beliefs about the legitimacy of parental authority and their own obligation to obey: A longitudinal investigation. Child Development, 79(4), 1103-1118. https://doi.org/10.1111/j.14678624.2008.01178.x

De Goede, I. H. A., Branje, S. J. T., \& Meeus, W. H. J. (2009). Developmental changes in adolescents' perceptions of relationships with their parents. Journal of Youth and Adolescence, 38(1), 75-88. https://doi.org/10.1007/s10964-008-9286-7

Dietvorst, E., Hiemstra, M., Hillegers, M. H. J., \& Keijsers, L. (2018). Adolescent Perceptions of Parental Privacy Invasion and Adolescent Secrecy: An Illustration of Simpson's Paradox. Child Development, 89(6), 2081-2090. https://doi.org/10.1111/cdev.13002 
Ellis, W. E., Dumas, T. M., \& Forbes, L. M. (2020). Physically isolated but socially connected: Psychological adjustment and stress among adolescents during the initial COVID-19 crisis. Canadian Journal of Behavioural Science, 52(3), 177-187. https://doi.org/10.1037/cbs0000215 Flora, D. B. (2008). Specifying piecewise latent trajectory models for longitudinal data. Structural Equation Modeling, 15(3), 513-533. https://doi.org/10.1080/10705510802154349

Furman, W., \& Buhrmester, D. (1985). Children's Perceptions of the Personal Relationships in Their Social Networks. Developmental Psychology, 21(6), 1016-1024.

Grolnick, W. S., Ryan, R. M., \& Deci, E. L. (1991). Inner resources for school achievement: Motivational mediators of children's perceptions of their parents. Journal of Educational Psychology, 83(4), 508-517. https://psycnet.apa.org/buy/1992-10834-001

Henry, C. S., Sheffield Morris, A., \& Harrist, A. W. (2015). Family Resilience: Moving into the Third Wave. Family Relations, 64(1), 22-43. https://doi.org/10.1111/fare.12106

Hiraoka, D., \& Tomoda, A. (2020). Relationship between parenting stress and school closures due to the COVID-19 pandemic. Psychiatry and Clinical Neurosciences, 497-498. https://doi.org/10.1111/pen.13088

Hutchison, B. S. R. M., \& Tomkunas, R. T. A. J. (2020). Initial challenges of caregiving during COVID-19: Caregiver burden, mental health, and the parent-child relationship. Child Psychiatry and Human Development, 51(5), 671-682. https://doi.org/10.1007/s10578-02001037-x

IBM Corp. (2016). IBM SPSS Statistics for Windows (24.0). IBM Corp.

Janssen, L. H. C., Kullberg, M. J., Verkuil, B., van Zwieten, N., Wever, M. C. M., van Houtum, L. A. E. M., Wentholt, W. G. M., \& Elzinga, B. M. (2020). Does the COVID-19 pandemic impact parents' and adolescents' well-being? An EMA-study on daily affect and parenting. PLOS ONE. https://doi.org/10.1371/journal.pone.0240962

Keijsers, L., Branje, S., Hawk, S. T., Schwartz, S. J., Frijns, T., Koot, H. M., van Lier, P., \& Meeus, 
W. (2012). Forbidden Friends as Forbidden Fruit: Parental Supervision of Friendships, Contact With Deviant Peers, and Adolescent Delinquency. Child Development, 83(2), 651-666. https://doi.org/10.1111/j.1467-8624.2011.01701.x

Keijsers, L., Voelkle, M. C., Maciejewski, D., Branje, S., Koot, H., Hiemstra, M., \& Meeus, W. (2016). What drives developmental change in adolescent disclosure and maternal knowledge? Heterogeneity in within-family processes. Developmental Psychology, 52(12), 2057-2070. https://doi.org/10.1037/dev0000220

Kerr, M., \& Stattin, H. (2000). What parents know, how they know it, and several forms of adolescent adjustment: further support for a reinterpretation of monitoring. Developmental Psychology, 36(3), 366-380. https://psycnet.apa.org/record/2000-03210-007

Kline, R. B. (2011). Principles and Practice of Structural Equation Modeling (Third Edition). In Clinical Orthopaedics and Related Research (Issue 245). Guilford publications. https://doi.org/10.1097/00003086-198908000-00042

Koepke, S., \& Denissen, J. J. A. (2012). Dynamics of identity development and separationindividuation in parent-child relationships during adolescence and emerging adulthood - A conceptual integration. Developmental Review, 32(1), 67-88. https://doi.org/10.1016/j.dr.2012.01.001

Laursen, B., Coy, K. C., \& Collins, W. A. (1998). Reconsidering changes in parent-child conflict across adolescence: a meta-analysis. Child Development, 69(3), 817-832. https://doi.org/10.1111/j.1467-8624.1998.tb06245.x

Laursen, B., DeLay, D., \& Adams, R. E. (2010). Trajectories of perceived support in motheradolescent relationships: The poor (quality) get poorer. Developmental Psychology, 46(6), 1792-1798. https://doi.org/10.1037/a0020679

Lionetti, F., Palladino, B. E., Moses Passini, C., Casonato, M., Hamzallari, O., Ranta, M., Dellagiulia, A., \& Keijsers, L. (2019). The development of parental monitoring during 
adolescence: A meta-analysis. European Journal of Developmental Psychology, 16(5), 552-580. https://doi.org/10.1080/17405629.2018.1476233

Loades, M. E., Chatburn, E., Higson-Sweeney, N., Reynolds, S., Shafran, R., Brigden, A., Linney, C., McManus, M. N., Borwick, C., \& Crawley, E. (2020). Rapid systematic review: The impact of social isolation and loneliness on the mental health of children and adolescents in the context of COVID-19. Journal of the American Academy of Child \& Adolescent Psychiatry, Advanced online publication. https://doi.org/10.1016/j.jaac.2020.05.009

Magson, N. R., Fardouly, J., Freeman, J. Y. A., Rapee, R. M., Richardson, C. E., \& Oar, E. L. (2020). Risk and protective factors for prospective changes in adolescent mental health during the COVID-19 pandemic. Journal of Youth and Adolescence. https://doi.org/10.1007/s10964-02001332-9

Malkawi, S. H., Almhdawi, K., Jaber, A. F., \& Alqatarneh, N. S. (2020). COVID-19 quarantine-related mental health symptoms and their correlates among mothers: A cross sectional study. Maternal and Child Health Journal. https://doi.org/10.1007/s10995-020-03034$\mathrm{X}$

Marques de Miranda, D., da Silva Athanasio, B., Cecília de Sena Oliveira, A., \& Simoes Silva, A. C. (2020). How is COVID-19 pandemic impacting mental health of children and adolescents? International Journal of Disaster Risk Reduction, 51(August), 101845. https://doi.org/10.1016/j.ijdrr.2020.101845

Marteau, T. M., \& Bekker, H. (1992). The development of a six-item short-form of the state scale of the Spielberger State-Trait Anxiety Inventory (STAI). British Journal of Clinical Psychology, 31(3), 301-306. https://doi.org/10.1111/j.2044-8260.1992.tb00997.x

Masten, A. S. (2001). Ordinary magic: Resilience processes in development. American Psychologist, 56(3), 227-238. https://doi.org/10.1037/0003-066X.56.3.227

Masten, A. S., \& Motti-Stefanidi, F. (2020). Multisystem resilience for children and youth in 
disaster: Reflections in the context of COVID-19. Adversity and Resilience Science, 1, 95-106. https://doi.org/10.1007/s42844-020-00010-w

Meeus, W. (2016). Adolescent psychosocial development: A review of longitudinal models and research. Developmental Psychology. https://doi.org/10.1037/dev0000243

Miller, J. J., Cooley, M. E., \& Mihalec, B. P. (2020). Examining the impact of COVID - 19 on parental stress: A study of foster parents. Child and Adolescent Social Work Journal. https://doi.org/10.1007/s10560-020-00725-w

Muthén, L. K., \& Muthén, B. (2017). Mplus User’s Guide (Muthén \& Muthén (Eds.)).

Patterson, J. M. (1988). Families experiencing stress. I. The family adjustment and adaptation response model. II. Applying the FAAR model to health-related issues for intervention and reasearch. Family Systems Medicine, 6(2), 202-237. https://doi.org/10.1037/h0089739

Patterson, J. M. (2002). Integrating family resilience and family stress theory. Journal of Marriage and Family, 64(2), 349-360. https://doi.org/10.1111/j.1741-3737.2002.00349.x

Petegem, S. Van, Vansteenkiste, M., Soenens, B., \& Audenaert, E. (2017). When Do Adolescents Accept or Defy to Maternal Prohibitions? The Role of Social Domain and Communication Style. Journal of Youth and Adolescence, 1022-1037. https://doi.org/10.1007/s10964-016-05627

Qualtrics. (2020). Qualtrics.

R Core Team. (2019). $R$ : A language and environment for statistical computing. $R$ Foundation for Statistical Computing. https://www.r-project.org/

Silk, J. S., Morris, A. S., Kanaya, T., \& Steinberg, L. (2003). Psychological control and autonomy granting: Opposite ends of a continuum or distinct constructs? Journal of Research on Adolescence, 13(1), 113-128. https://doi.org/10.1111/1532-7795.1301004

Smetana, J. G. (2017). Current research on parenting styles, dimensions, and beliefs. Current Opinion in Psychology, 15(February), 19-25. https://doi.org/10.1016/j.copsyc.2017.02.012 
Smetana, J. G., \& Asquith, P. (1994). Adolescents' and Parents' Conceptions of Parental Authority and Personal Autonomy. Child Development, 65(4), 1147-1162. https://doi.org/10.1111/j.14678624.1994.tb00809.x

Smetana, J. G., Campione-Barr, N., \& Metzger, A. (2006). Adolescent Development in Interpersonal and Societal Contexts. Annual Review of Psychology, 57, 255-284.

https://doi.org/10.1146/annurev.psych.57.102904.190124

Soenens, B., Vansteenkiste, M., Lens, W., Luyckx, K., Goossens, L., Beyers, W., \& Ryan, R. M. (2007). Conceptualizing parental autonomy support: Adolescent perceptions of promotion of independence versus promotion of volitional functioning. Developmental Psychology, 43(3), 633-646. https://doi.org/10.1037/0012-1649.43.3.633

Soenens, B., Vansteenkiste, M., \& Van Petegem, S. (Eds.). (2017). Autonomy in adolescent development: Towards conceptual clarity. Psychology Press.

Spinelli, M., Lionetti, F., Pastore, M., \& Fasolo, M. (2020). Parents'stress and children's psychological problems in families facing the COVID-19 outbreak in Italy. Frontiers in Psychology, 11(January), 1-7. https://doi.org/10.3389/fpsyg.2020.01713

Steinberg, L., \& Silk, J. S. (2002). Parenting Adolescents. In M. H. Bornstein (Ed.), Handbook of Parenting : Children and Parenting (2nd ed., Vol. 1, pp. 103-134). Lawrence Erlbaum Associates, Inc.

Van Der Bij, A. K., De Weerd, S., Cikot, R. J. L. M., Steegers, E. A. P., \& Braspenning, J. C. C. (2003). Validation of the Dutch short form of the state scale of the Spielberger State-Trait Anxiety Inventory: Considerations for usage in screening outcomes. Community Genetics, 6(2), 84-87. https://doi.org/10.1159/000073003

Van Der Kaap-Deeder, J., Soenens, B., Mabbe, E., Dieleman, L., Mouratidis, A., Campbell, R., \& Vansteenkiste, M. (2019). From Daily Need Experiences to Autonomy-Supportive and Psychologically Controlling Parenting via Psychological Availability and Stress. Parenting, 
19(3), 177-202. https://doi.org/10.1080/15295192.2019.1615791

Van Eldik, W. M., de Haan, A. D., Parry, L. Q., Davies, P. T., Luijk, M. P. C. M., Arends, L. R., \& Prinzie, P. (2020). The interparental relationship: Meta-analytic associations with children's maladjustment and responses to interparental conflict. Psychological Bulletin, 146(7), 553-594. https://doi.org/10.1037/bu10000233

Van Petegem, S., Soenens, B., Vansteenkiste, M., \& Beyers, W. (2015). Rebels with a cause? Adolescent defiance from the perspective of reactance theory and self-determination theory. Child Development, 86(3), 903-918. https://doi.org/10.1111/cdev.12355

Van Petegem, S., Vansteenkiste, M., \& Beyers, W. (2013). The Jingle-Jangle Fallacy in Adolescent Autonomy in the Family: In Search of an Underlying Structure. Journal of Youth and Adolescence, 42(7), 994-1014. https://doi.org/10.1007/s10964-012-9847-7

Vansteenkiste, M., Soenens, B., Van Petegem, S., \& Duriez, B. (2014). Longitudinal associations between adolescent perceived degree and style of parental prohibition and internalization and defiance. Developmental Psychology, 50(1), 229-236. https://doi.org/10.1037/a0032972

Wainer, H. (2000). The centercept: An estimable and meaningful regression parameter. In Psychological Science (Vol. 11, Issue 5, pp. 434-436). Blackwell Publishing Ltd. https://doi.org/10.1111/1467-9280.00284

Widaman, K. F., \& Thompson, J. S. (2003). On Specifying the Null Model for Incremental Fit Indices in Structural Equation Modeling. Psychological Methods, 8(1), 16-37. https://doi.org/10.1037/1082-989X.8.1.16 
Table 1

Overview of timing of measurements

\begin{tabular}{|c|c|c|c|c|c|c|c|c|}
\hline \multirow{2}{*}{ Construct } & \multicolumn{8}{|c|}{ Measurement wave } \\
\hline & LD-4 & LD-3 & LD-2 & LD-1 & LD+1 & $\mathrm{LD}+2$ & $\mathrm{LD}+3$ & $\mathrm{LD}+4$ \\
\hline \multicolumn{9}{|l|}{ Relationship dimensions } \\
\hline Parental warmth & $\mathrm{x}$ & $\mathrm{x}$ & $\mathrm{x}$ & $\mathrm{x}$ & $\mathrm{x}$ & $\mathrm{x}$ & $\mathrm{x}$ & $\mathrm{x}$ \\
\hline Parent-child conflict & $\mathrm{x}$ & $\mathrm{X}$ & $\mathrm{x}$ & $\mathrm{x}$ & $\mathrm{X}$ & $\mathrm{x}$ & $\mathrm{x}$ & $\mathrm{x}$ \\
\hline Autonomy support & $\mathrm{x}$ & $\mathrm{x}$ & $\mathrm{x}$ & $\mathrm{x}$ & $\mathrm{x}$ & $\mathrm{x}$ & $\mathrm{x}$ & $\mathrm{x}$ \\
\hline Psychological control & $\mathrm{x}$ & $\mathrm{x}$ & $\mathrm{x}$ & $\mathrm{x}$ & $\mathrm{x}$ & $\mathrm{x}$ & $\mathrm{x}$ & $\mathrm{x}$ \\
\hline Behavioral control & $\mathrm{x}$ & $\mathrm{x}$ & $\mathrm{x}$ & $\mathrm{x}$ & $\mathrm{x}$ & $\mathrm{x}$ & $\mathrm{x}$ & $\mathrm{x}$ \\
\hline \multicolumn{9}{|l|}{ COVID-19 specific measures } \\
\hline Time with parents and peers & & & & & $\mathrm{x}$ & & & \\
\hline COVID 19-related rules & & & & & & $\mathrm{x}$ & & \\
\hline Oppositional defiance & & & & & & $\mathrm{x}$ & & \\
\hline Legitimacy beliefs & & & & & & $\mathrm{x}$ & & \\
\hline Parental anxiety and worry & & & & & & $\mathrm{x}$ & & \\
\hline
\end{tabular}


Table 2

Descriptive Statistics of Longitudinal Data

\begin{tabular}{|c|c|c|c|c|c|c|c|c|c|}
\hline \multirow[t]{2}{*}{ Variable } & \multicolumn{2}{|c|}{ Adolescent } & \multicolumn{2}{|c|}{ Parent } & \multicolumn{5}{|c|}{ Respondent difference ${ }^{\mathrm{a}}$} \\
\hline & $M$ & $S D$ & $M$ & $S D$ & $t$ & $d f$ & $p$ & $d$ & $95 \% \mathrm{CI}$ \\
\hline \multicolumn{10}{|l|}{ Parental warmth } \\
\hline LD-4 & 4.61 & 0.54 & 4.55 & 0.40 & 1.07 & 308 & .284 & 0.12 & {$[-0.05,0.17]$} \\
\hline LD-3 & 4.63 & 0.50 & 4.51 & 0.45 & 2.24 & 301 & .026 & 0.26 & {$[0.01,0.23]$} \\
\hline LD-2 & 4.62 & 0.54 & 4.55 & 0.47 & 1.21 & 303 & .226 & 0.14 & {$[-0.04,0.19]$} \\
\hline LD-1 & 4.64 & 0.54 & 4.54 & 0.42 & 1.71 & 287 & .089 & 0.20 & {$[-0.02,0.21]$} \\
\hline $\mathrm{LD}+1$ & 4.63 & 0.53 & 4.54 & 0.47 & 1.56 & 270 & .120 & 0.19 & {$[-0.02,0.21]$} \\
\hline $\mathrm{LD}+2$ & 4.63 & 0.54 & 4.48 & 0.48 & 2.42 & 269 & .016 & 0.29 & {$[0.03,0.27]$} \\
\hline $\mathrm{LD}+3$ & 4.62 & 0.48 & 4.53 & 0.44 & 1.55 & 245 & .123 & 0.20 & {$[-0.02,0.21]$} \\
\hline $\mathrm{LD}+4$ & 4.66 & 0.48 & 4.54 & 0.44 & 2.27 & 276 & .024 & 0.27 & {$[0.02,0.24]$} \\
\hline
\end{tabular}

Parent-adolescent conflict

$\begin{array}{llllllllll}\text { LD-4 } & 1.84 & 0.76 & 1.93 & 0.73 & 1.04 & 307 & .298 & 0.12 & {[-0.26,0.08]} \\ \text { LD-3 } & 1.67 & 0.67 & 1.96 & 0.73 & 3.55 & 301 & <.001 & 0.41 & {[-0.44,-0.13]} \\ \text { LD-2 } & 1.75 & 0.69 & 1.97 & 0.76 & 2.64 & 303 & .009 & 0.30 & {[-0.38,-0.06]} \\ \text { LD-1 } & 1.78 & 0.76 & 1.92 & 0.71 & 1.65 & 286 & .100 & 0.19 & {[-0.31,0.03]} \\ \text { LD+1 } & 1.77 & 0.72 & 1.95 & 0.72 & 2.11 & 270 & .036 & 0.26 & {[-0.35,-0.01]} \\ \text { LD+2 } & 1.78 & 0.81 & 2.01 & 0.73 & 2.38 & 268 & .018 & 0.29 & {[-0.41,-0.04]} \\ \text { LD+3 } & 1.80 & 0.72 & 1.92 & 0.69 & 1.37 & 245 & .171 & 0.18 & {[-0.30,0.05]} \\ \text { LD+4 } & 1.78 & 0.76 & 1.94 & 0.66 & 1.93 & 276 & .054 & 0.23 & {[-0.33,0.00]}\end{array}$

Autonomy support

LD-4
LD-3
LD-2
LD-1
LD+1
LD+2
LD+3
LD+4

$\begin{array}{llll}4.17 & 0.69 & 4.27 & 0.48 \\ 4.20 & 0.70 & 4.24 & 0.51 \\ 4.24 & 0.64 & 4.22 & 0.53 \\ 4.25 & 0.64 & 4.24 & 0.51 \\ 4.14 & 0.67 & 4.01 & 0.68 \\ 4.12 & 0.77 & 4.06 & 0.65 \\ 4.18 & 0.73 & 4.25 & 0.58 \\ 4.22 & 0.69 & 4.24 & 0.53\end{array}$

$\begin{array}{lll}1.50 & 298.65^{\mathrm{b}} \quad .136\end{array}$

$\begin{array}{lll}0.52 & 295.09^{\mathrm{b}} \quad .603\end{array}$

$\begin{array}{lll}0.32 & 302.72^{\mathrm{b}} \quad .748\end{array}$

$0.19 \quad 282.94^{\mathrm{b}} \quad .852$

$\begin{array}{lll}1.55 & 270 \quad .121\end{array}$

$\begin{array}{lll}0.65 & 266.95^{\mathrm{b}} \quad .518\end{array}$

$0.79 \quad 228.15^{\mathrm{b}} \quad .428$

$0.18 \quad 266.70^{\mathrm{b}} \quad .859$

$0.17 \quad[-0.23,0.03]$

$0.06 \quad[-0.17,0.10]$

$0.04 \quad[-0.11,0.15]$

$0.02 \quad[-0.12,0.15]$

$0.19 \quad[-0.03,0.29]$

$0.08 \quad[-0.11,0.22]$

$\begin{array}{ll}0.10 & {[-0.23,0.10]} \\ 0.02 & {[-0.16,0.13]}\end{array}$

Psychology control

$\begin{array}{lllllllllr}\text { LD-4 } & 1.35 & 0.58 & 1.20 & 0.34 & 2.80 & 280.83^{\mathrm{b}} & .005 & 0.31 & {[0.04,0.25]} \\ \text { LD-3 } & 1.29 & 0.50 & 1.20 & 0.35 & 1.66 & 301 & .098 & 0.19 & {[-0.2,0.18]} \\ \text { LD-2 } & 1.32 & 0.56 & 1.20 & 0.37 & 2.33 & 288.02^{\mathrm{b}} & .021 & 0.26 & {[0.02,0.23]} \\ \text { LD-1 } & 1.28 & 0.56 & 1.21 & 0.34 & 1.20 & 287 & .232 & 0.14 & {[-0.04,0.18]} \\ \text { LD+1 } & 1.25 & 0.49 & 1.21 & 0.38 & 0.75 & 270 & .452 & 0.09 & {[-0.06,0.14]} \\ \text { LD+2 } & 1.27 & 0.57 & 1.20 & 0.35 & 1.16 & 268 & .248 & 0.14 & {[-0.05,0.18]} \\ \text { LD+3 } & 1.29 & 0.60 & 1.15 & 0.33 & 2.30 & 183.30^{\mathrm{b}} & .023 & 0.30 & {[0.02,0.27]} \\ \text { LD+4 } & 1.29 & 0.57 & 1.22 & 0.39 & 1.08 & 276 & .280 & 0.13 & {[-0.05,0.28]}\end{array}$

Behavioral control

\begin{tabular}{lccccccccc} 
LD-4 & 2.52 & 1.37 & 1.90 & 1.06 & 4.47 & $306.85^{\mathrm{b}}$ & $<.001$ & 0.50 & {$[0.35,0.89]$} \\
LD-3 & 2.42 & 1.26 & 1.93 & 1.04 & 3.74 & $300.88^{\mathrm{b}}$ & $<.001$ & 0.42 & {$[0.23,0.75]$} \\
LD-2 & 2.49 & 1.30 & 1.86 & 1.01 & 4.78 & $302.06^{\mathrm{b}}$ & $<.001$ & 0.54 & {$[0.37,0.89]$} \\
LD-1 & 2.48 & 1.31 & 2.03 & 1.14 & 3.14 & $286.99^{\mathrm{b}}$ & .002 & 0.37 & {$[0.17,0.74]$} \\
LD+1 & 2.31 & 1.32 & 2.05 & 1.17 & 1.72 & 271 & .086 & 0.21 & {$[-0.04,0.56]$} \\
LD+2 & 2.38 & 1.46 & 1.99 & 1.15 & 2.42 & 262.35 & .016 & 0.29 & {$[0.07,0.70]$} \\
LD+3 & 2.48 & 1.53 & 1.84 & 1.09 & 3.75 & 213.90 & $<.001$ & 0.48 & {$[0.30,0.97]$} \\
LD+4 & 2.38 & 1.48 & 1.95 & 1.09 & 2.79 & 262.47 & .006 & 0.33 & {$[0.13,0.74]$} \\
\hline
\end{tabular}

Note. ${ }^{\text {a }}$ Unpaired t-tests. Paired t-tests in Table S1. ${ }^{\mathrm{b}}$ correction for unequal variances 
Table 3

Time With Family and Friends Before and During Lockdown (Hours per Day)

\begin{tabular}{|c|c|c|c|c|c|c|c|c|c|}
\hline \multirow[t]{2}{*}{ Time with } & \multicolumn{2}{|c|}{$\begin{array}{c}\text { Before } \\
\text { (retrospective) }\end{array}$} & \multicolumn{2}{|c|}{$\begin{array}{l}\text { Currently } \\
(\mathrm{LD}+1)\end{array}$} & \multicolumn{5}{|c|}{ Difference [Before vs. Currently] } \\
\hline & M & $S D$ & M & $S D$ & $t$ & $d f$ & $p$ & $d$ & $95 \% \mathrm{CI}$ \\
\hline \multicolumn{10}{|l|}{ Adolescent report } \\
\hline Primary caregiver (week) & 8.55 & 5.47 & 12.72 & 6.94 & 10.13 & 140 & $<.001$ & 0.65 & {$[3.36,4.99]$} \\
\hline Primary caregiver (weekend) & 12.34 & 6.18 & 14.13 & 6.82 & 5.19 & 140 & $<.001$ & 0.27 & {$[1.11,2.47]$} \\
\hline Secondary caregiver (week) & 7.00 & 5.32 & 10.52 & 7.04 & 8.76 & 140 & $<.001$ & 0.54 & {$[2.75,4.45]$} \\
\hline Secondary caregiver (weekend) & 11.31 & 6.38 & 12.70 & 7.26 & 3.93 & 140 & $<.001$ & 0.20 & {$[0.69,2.09]$} \\
\hline Friends (week) & 8.14 & 3.53 & 2.14 & 3.02 & -17.15 & 140 & $<.001$ & -1.82 & {$[6.69,5.31]$} \\
\hline Friends (weekend) & 6.60 & 5.79 & 2.34 & 3.72 & -9.79 & 140 & $<.001$ & -0.84 & {$[-1.04,-0.64]$} \\
\hline Friends (online/phone) & 3.23 & 3.69 & 5.64 & 4.41 & 8.63 & 140 & $<.001$ & 0.58 & {$[1.98,2.96]$} \\
\hline \multicolumn{10}{|l|}{ Parent report } \\
\hline Adolescent (week) & 5.95 & 3.76 & 10.55 & 6.70 & 12.14 & 130 & $<.001$ & 0.67 & {$[3.85,5.35]$} \\
\hline Adolescent (weekend) & 10.31 & 5.23 & 12.76 & 6.31 & 7.11 & 130 & $<.001$ & 0.41 & {$[1.77,3.13]$} \\
\hline
\end{tabular}

Note. Differences were calculated with paired t-tests, comparing participants reports about the situation before the lockdown and during the lockdown (both measured at $\mathrm{LD}+1$ ). 


\section{Table 4}

Descriptive Statistics for Single Measurements $(L D+1)$

\begin{tabular}{llll}
\hline Variable (Respondent) & $M$ & $S D$ & Range \\
\hline Number COVID-19 rules (A) & 13.04 & 3.96 & $2-16$ \\
Number COVID-19 rules (P) & 14.36 & 3.04 & $2-19$ \\
Legitimacy beliefs regarding COVID-19 rules (A) & 2.12 & 0.46 & $1-3$ \\
Oppositional defiance (A) & 1.31 & 0.58 & $1-4$ \\
Oppositional defiance (P) & 1.45 & 0.64 & $1-3.5$ \\
Parental anxiety (P) & 2.02 & 0.57 & $1-3.4$ \\
Parental worry about COVID-19 (P) & 2.62 & 0.75 & $1-4$ \\
\hline
\end{tabular}

Note. $\mathrm{A}=$ Adolescent, $\mathrm{P}=$ Parent. 
Table 5

New COVID-19 Rules

\begin{tabular}{|c|c|c|c|c|c|}
\hline & & \multicolumn{2}{|c|}{ Adolescents } & \multicolumn{2}{|c|}{ Parents } \\
\hline Domain & Rule & $N$ & $\%$ & $N$ & $\%$ \\
\hline \multirow[t]{10}{*}{ Daily routines } & Get up on time & 86 & 61 & 94 & 73 \\
\hline & Have a schedule & 70 & 50 & 97 & 75 \\
\hline & Help with household & 67 & 48 & 66 & 51 \\
\hline & Go outside regularly & 92 & 66 & 101 & 78 \\
\hline & Avoid going outside & 41 & 29 & 22 & 17 \\
\hline & Do not go outside & 5 & 4 & 0 & 0 \\
\hline & Keep sporting & 94 & 67 & 114 & 88 \\
\hline & Do homework & 99 & 71 & 115 & 89 \\
\hline & Less phone use/gaming & 11 & 8 & 6 & 5 \\
\hline & $\begin{array}{l}\text { More phone } \\
\text { use/gaming }\end{array}$ & 60 & 43 & 76 & 59 \\
\hline \multirow[t]{3}{*}{ Friends } & Restrict meeting friends & 105 & 75 & 99 & 77 \\
\hline & Meet only one friend & 52 & 37 & 81 & 63 \\
\hline & Meet no friends & 30 & 21 & 37 & 29 \\
\hline \multirow[t]{4}{*}{ Health } & Eat healthy & 63 & 45 & 53 & 41 \\
\hline & Wash hands* & 120 & 85 & 112 & 87 \\
\hline & Extra hygiene & 57 & 41 & 26 & 20 \\
\hline & Cough in elbow* & 125 & 89 & 124 & 96 \\
\hline \multirow[t]{6}{*}{ Social distancing } & $\begin{array}{l}\text { Do not visit } \\
\text { grandparents }\end{array}$ & 111 & 79 & 102 & 79 \\
\hline & Do no visit parents ${ }^{\mathrm{a}}$ & 55 & 39 & 40 & 31 \\
\hline & Keep Distance & 128 & 91 & 127 & 98 \\
\hline & Avoid crowded places* & 109 & 78 & 117 & 91 \\
\hline & Avoid physical contact* & 117 & 84 & 115 & 89 \\
\hline & Stay at home if sick* & 135 & 96 & 129 & 100 \\
\hline
\end{tabular}

Note. *Dutch governmental rules to avoid spreading of COVID-19

${ }^{\text {a }}$ We intended to ask if they were restricted in seeing one of their parents (when parents are separated and living apart), but given the high ratings of children who lived with both parents on this item, we suspect that this item was misinterpreted by some adolescents, as the Dutch word of parent is similar to the Dutch word of elderly. Therefore, this item should be interpreted with caution. 
Legitimacy Beliefs Concerning New COVID-19 Rules

\begin{tabular}{llccc}
\hline \multicolumn{1}{c}{ Domain } & \multicolumn{1}{c}{ Rule } & Disagree & $\begin{array}{c}\text { Agree } \\
\text { somewhat }\end{array}$ & $\begin{array}{c}\text { Totally } \\
\text { agree }\end{array}$ \\
\hline Daily routines & Leisure time & $24 \%$ & $\mathbf{4 7 \%}$ & $29 \%$ \\
& Have Schedule & $40 \%$ & $\mathbf{4 8 \%}$ & $12 \%$ \\
& Do homework & $34 \%$ & $\mathbf{4 1 \%}$ & $26 \%$ \\
& Go outside & $21 \%$ & $\mathbf{4 9 \%}$ & $31 \%$ \\
Friends & Sport & $22 \%$ & $\mathbf{4 9 \%}$ & $29 \%$ \\
Health & Activities with friends & $14 \%$ & $37 \%$ & $\mathbf{4 9 \%}$ \\
& Eat healthy & $31 \%$ & $\mathbf{4 4 \%}$ & $25 \%$ \\
Social distancing & Hygiene & $25 \%$ & $\mathbf{4 6 \%}$ & $29 \%$ \\
& See family & $9 \%$ & $35 \%$ & $\mathbf{5 6 \%}$ \\
& Keep distance & $7 \%$ & $29 \%$ & $\mathbf{6 4 \%}$ \\
\hline
\end{tabular}

Note. Answers to the question: "Given the coronavirus pandemic, it is okay that my parents installed rules about ...". The bold value indicates the highest percentage per rule. 
Table 7

Model Results of Piece-Wise Growth Models

\begin{tabular}{|c|c|c|c|c|c|c|}
\hline \multirow[b]{2}{*}{ Measure (Respondent) } & \multirow[b]{2}{*}{$\begin{array}{l}\text { Growth } \\
\text { factors }\end{array}$} & \multicolumn{4}{|c|}{ Estimates } & \multirow{2}{*}{$\begin{array}{c}\text { Model fit }^{\mathrm{d}} \\
\text { RMSEA } \\
\text { CFI } \\
\text { TLI }\end{array}$} \\
\hline & & $M$ & $S E$ & Variance & $S E$ & \\
\hline \multirow[t]{4}{*}{ Parental Warmth (A) } & L1 & $4.63 * * *$ & 0.04 & $0.25 * * *$ & 0.03 & .04 \\
\hline & $\mathrm{S} 1$ & 0.01 & 0.01 & $0.01 * *$ & 0.00 & .99 \\
\hline & L2 & -0.02 & 0.04 & $0.11 * * *$ & 0.03 & .99 \\
\hline & $\mathrm{S} 2$ & 0.00 & 0.01 & 0.01 & 0.00 & \\
\hline \multirow{4}{*}{$\begin{array}{l}\text { Parent-Adolescent } \\
\text { Conflict (A) }\end{array}$} & $\mathrm{L} 1$ & $1.75^{* * *}$ & 0.05 & $0.35 * * *$ & 0.05 & .09 \\
\hline & $\mathrm{S} 1$ & -0.01 & 0.02 & 0.00 & 0.01 & .97 \\
\hline & $\mathrm{L} 2$ & 0.10 & 0.06 & $-0.03^{b}$ & 0.09 & .96 \\
\hline & $\mathrm{S} 2$ & 0.00 & 0.02 & 0.01 & 0.01 & \\
\hline \multirow[t]{4}{*}{ Autonomy Support(A) } & L1 & $4.22 * * *$ & 0.05 & $0.31 * * *$ & 0.05 & .04 \\
\hline & $\mathrm{S} 1$ & 0.01 & 0.02 & 0.01 & 0.01 & .99 \\
\hline & $\mathrm{L} 2$ & $-0.16 * *$ & 0.06 & $0.25 * *$ & 0.09 & .99 \\
\hline & $\mathrm{S} 2$ & 0.02 & 0.02 & $0.04 * * *$ & 0.01 & \\
\hline \multirow{4}{*}{$\begin{array}{l}\text { Psychological Control } \\
\text { (A) })^{\mathrm{a}}\end{array}$} & L1 & $1.29 * * *$ & 0.04 & $0.22 * * *$ & 0.04 & .09 \\
\hline & $\mathrm{S} 1$ & - & - & - & - & .83 \\
\hline & L2 & - & - & - & - & .86 \\
\hline & $\mathrm{S} 2$ & - & - & - & - & \\
\hline \multirow[t]{4}{*}{ Behavioral Control (A) } & L1 & $2.55^{* * *}$ & 0.10 & $1.26^{* * *}$ & 0.18 & .08 \\
\hline & $\mathrm{S} 1$ & 0.02 & 0.02 & 0.01 & 0.02 & .98 \\
\hline & $\mathrm{L} 2$ & -0.11 & 0.10 & 0.01 & 0.23 & .97 \\
\hline & $\mathrm{S} 2$ & -0.02 & 0.03 & 0.03 & 0.03 & \\
\hline \multirow[t]{4}{*}{ Parental Warmth (P) } & L1 & $4.54 * * *$ & 0.04 & $0.15 * * *$ & 0.02 & .06 \\
\hline & $\mathrm{S} 1$ & 0.00 & 0.01 & 0.003 & 0.00 & .99 \\
\hline & $\mathrm{L} 2$ & -0.03 & 0.04 & 0.04 & 0.03 & .99 \\
\hline & $\mathrm{S} 2$ & 0.00 & 0.01 & $0.01 * *$ & 0.00 & \\
\hline \multirow{4}{*}{$\begin{array}{l}\text { Parent-Adolescent } \\
\text { Conflict (P) }\end{array}$} & L1 & $1.92 * * *$ & 0.06 & $0.48 * * *$ & 0.06 & .08 \\
\hline & S1 & -0.01 & 0.01 & 0.01 & 0.01 & .98 \\
\hline & $\mathrm{L} 2$ & 0.09 & 0.06 & $0.21 *$ & 0.09 & .98 \\
\hline & $\mathrm{S} 2$ & $<0.01$ & 0.02 & $0.02 *$ & 0.01 & \\
\hline \multirow[t]{4}{*}{ Autonomy Support (P) } & L1 & $4.21 * * *$ & 0.04 & $0.16 * * *$ & 0.03 & .10 \\
\hline & $\mathrm{S} 1$ & -0.02 & 0.01 & 0.00 & 0.00 & .95 \\
\hline & $\mathrm{L} 2$ & $-0.19 * *$ & 0.06 & 0.08 & 0.08 & .94 \\
\hline & $\mathrm{S} 2$ & $0.10 * * *$ & 0.02 & 0.01 & 0.01 & \\
\hline Psychological Control & L1 & $1.20 * * *$ & 0.03 & $0.07 * * *$ & 0.02 & .00 \\
\hline
\end{tabular}


(P)

$\begin{array}{llllll}\text { S1 } & 0.00 & 0.01 & 0.02 & 0.00 & 1.00 \\ \text { L2 } & 0.00 & 0.03 & -0.01^{\mathrm{b}} & 0.04 & 1.04 \\ \text { S2 } & <0.02 & 0.01 & 0.00 & 0.00 & \end{array}$

$\begin{array}{llllllr}\text { Behavioral Control (P) } & \text { L1 } & 2.00^{* * * *} & 0.09 & 0.99 * * * & 0.15 & .04 \\ & \text { S1 } & 0.03 & 0.02 & 0.02 & 0.01 & 1.00 \\ & \text { L2 } & 0.00 & 0.10 & \mathbf{0 . 3 2} * \mathbf{c} & 0.18 & .99 \\ & \text { S2 } & -0.06^{*} & 0.03 & 0.03 & 0.02 & \end{array}$

Note. Variances were tested one-sided, as they cannot $<0, \mathrm{~A}=$ Adolescent, $\mathrm{P}=$ Parent.

${ }^{a}$ Model fit did not meet our standards, ${ }^{b}$ Heywood cases (variance $<0$ ), sensitivity tests were conducted. ${ }^{c}$ When correcting the alpha level for multiple testing (hypotheses tested twice for both informants), this effect did not reach significance and should be interpreted cautiously. ${ }^{\mathrm{d}}$ These fit indices were calculated with Mplus; alternative fit indices according to Widaman and Thompson (2003) can be found in Table S3. L1 (level 1 or intercept) reflects the baseline functioning. S1 (Slope 1) reflects normative linear gradual change over the course of the whole study. L2 (level 2 or intercept) reflects the sudden lockdown change, controlling for L1 and S1, and is used to test Hypothesis 1. S2 (Slope 2) reflects gradual linear lockdown change that cannot be explained by S1 or by L1 or L2. Variance around L2 is used to test Hypothesis 2. In bold, parameters that support the hypotheses.

$* p<.05 . * * p<.01 . * * * p<.001$. 


\section{Figure 1}

Timeline of Dutch Governmental Measures to Restrict Spreading of COVID-19 and First Infection and Death Due to COVID-19 (Free Icons from the Streamline Icons pack, https://streamlineicons.com)

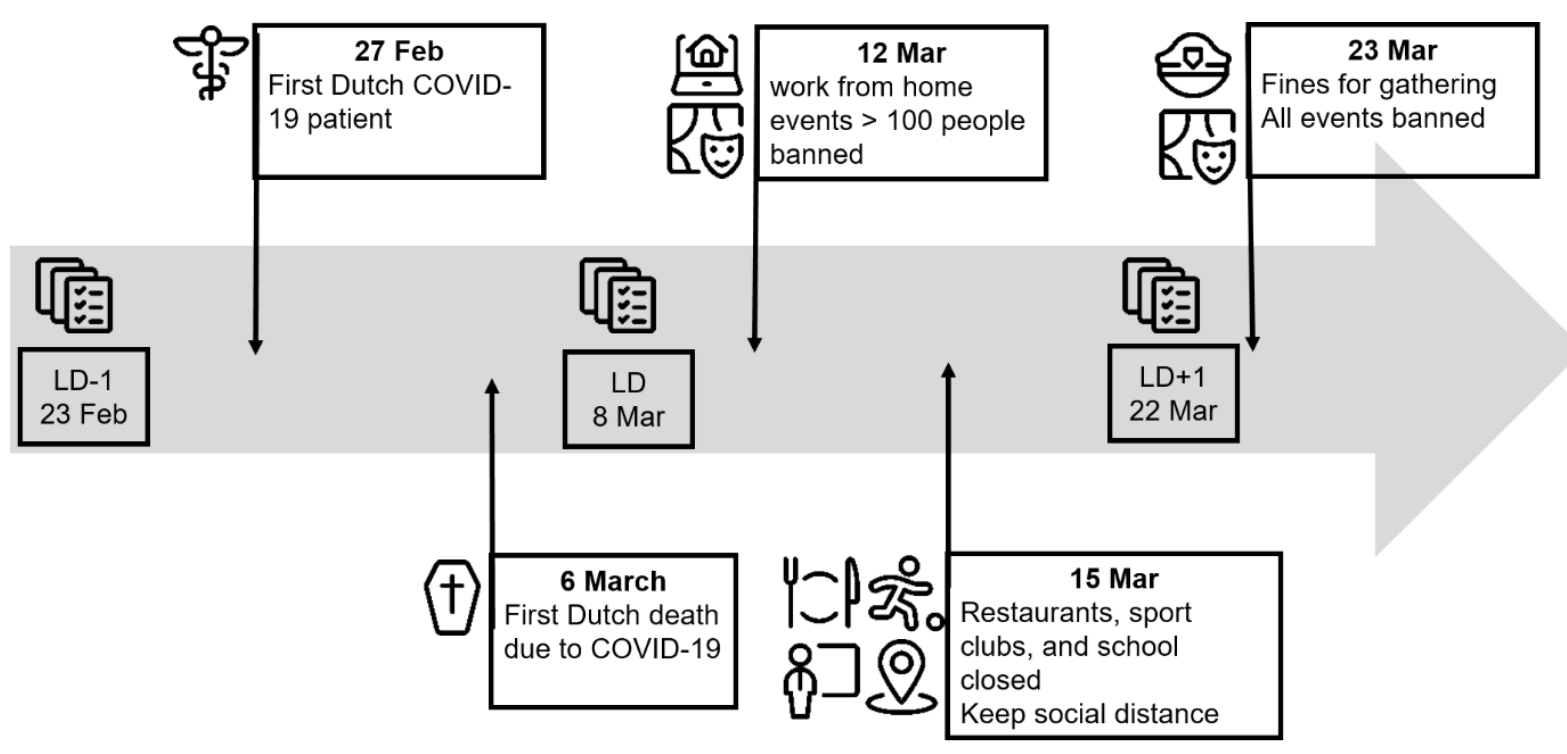


Figure 2

Specification of Piece-Wise Growth Model (Model 1)

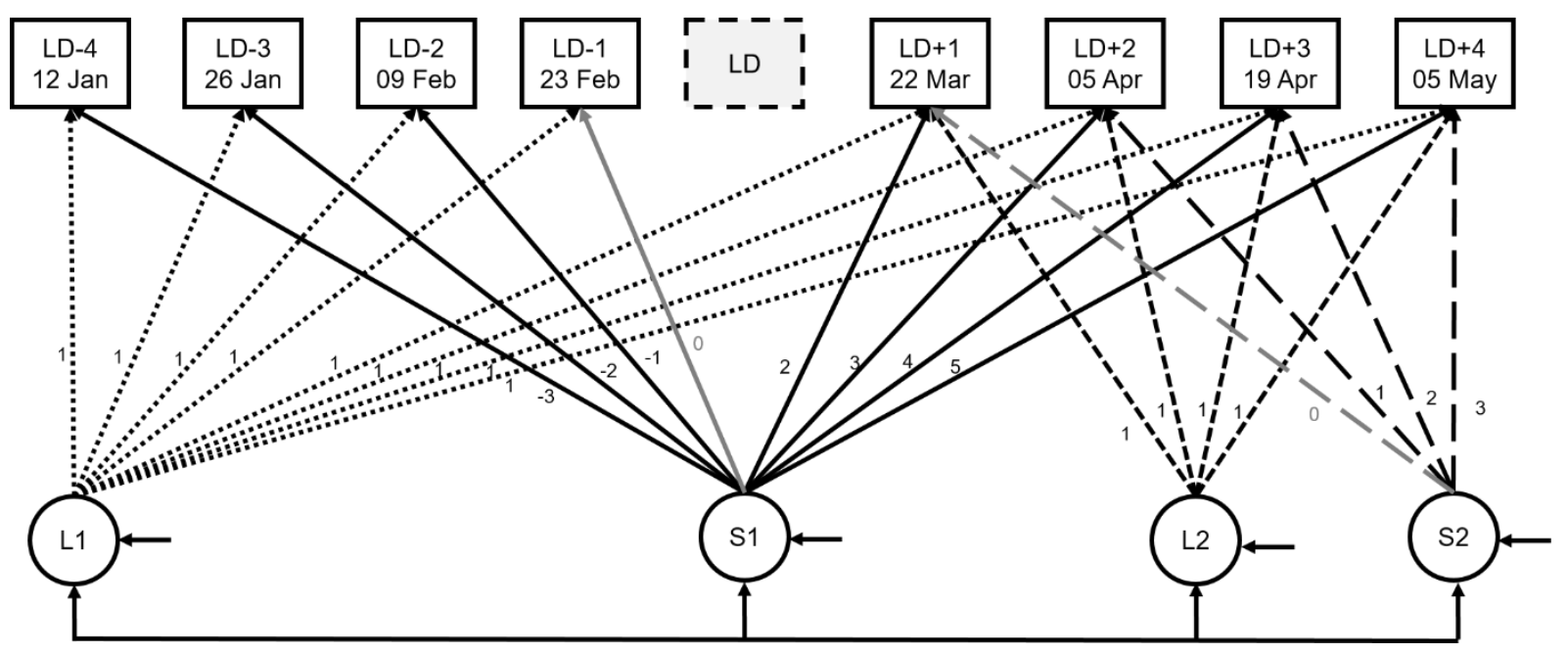

Note. $\mathrm{LD}=$ Lockdown 


\section{Figure 3}

Change in Autonomy Support Over Time
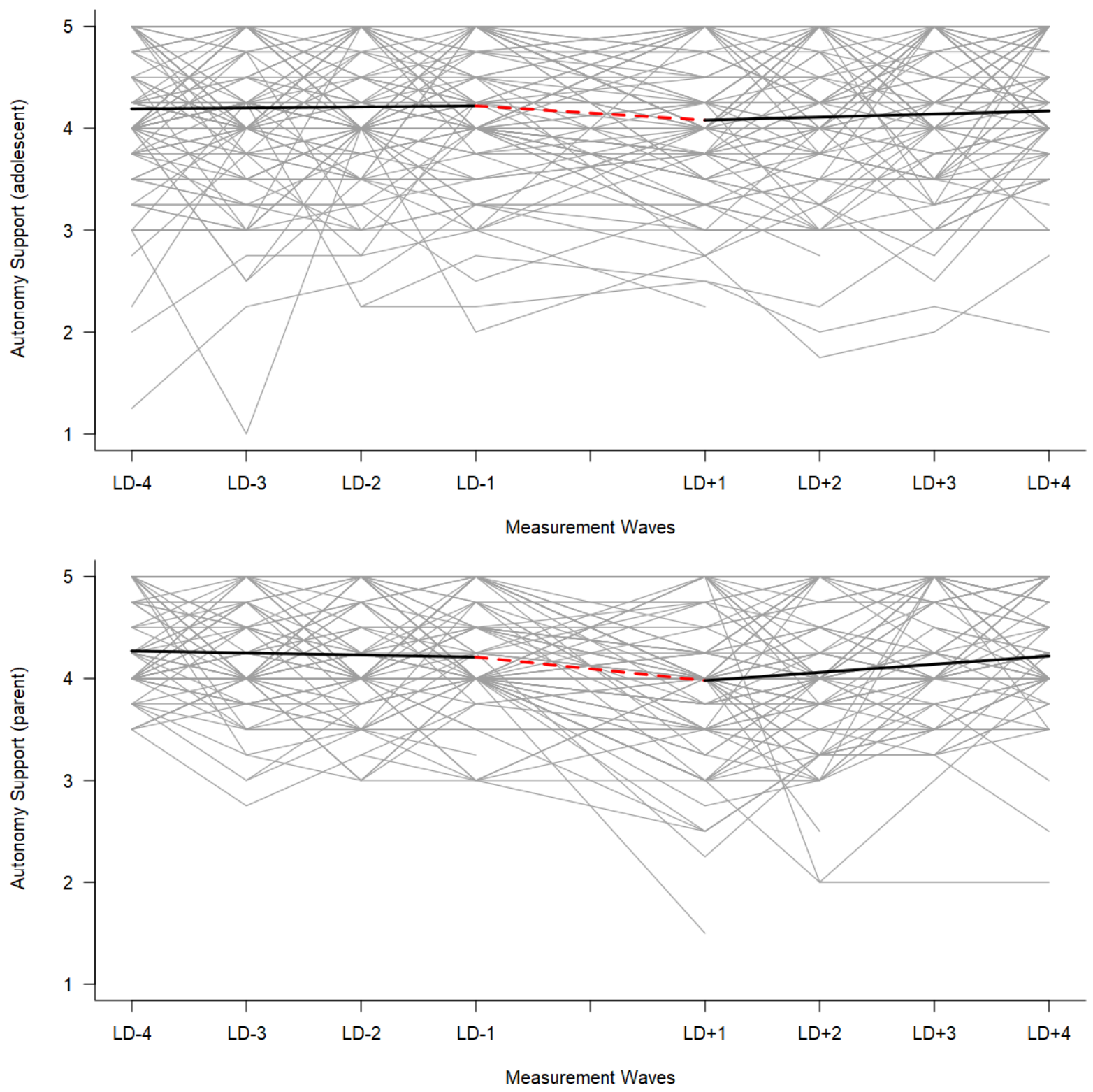

Note. Grey lines indicate observed scores. Bold lines indicate average estimated mean level change. Red dotted line depicts average mean level change when lockdown started. The upper panel depicts adolescent-reported autonomy support $(N=179)$, the lower panel parent-reported autonomy support $(N=144)$. 


\section{Figure 4}

Change in Parent-Adolescent Conflict from Parent-Report
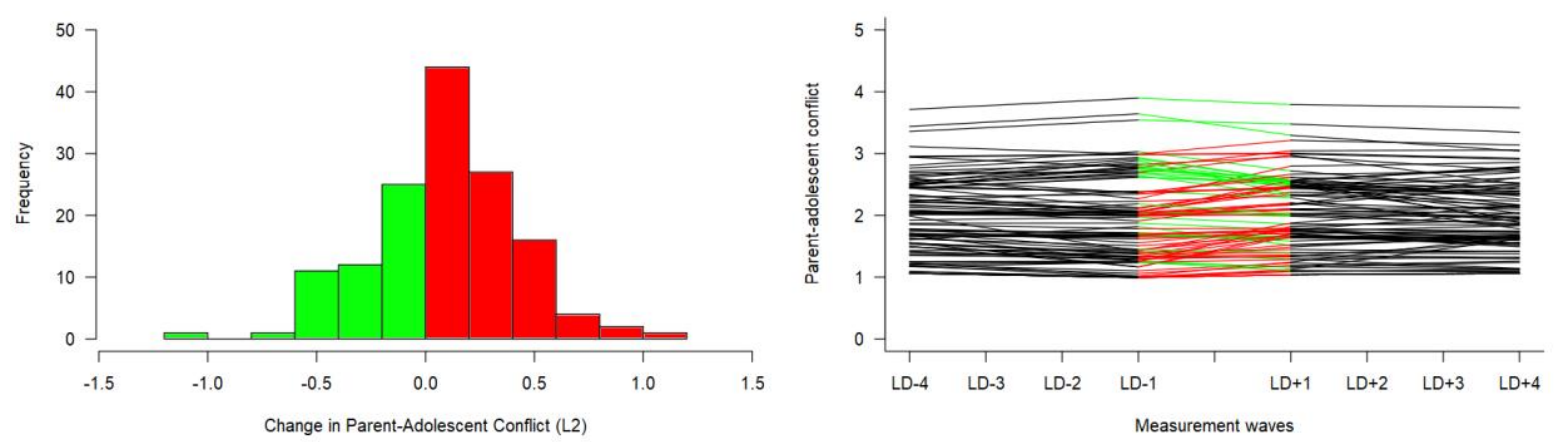

Note. Left panel: distribution of change parameter L2 in parent-adolescent conflict during lockdown.

Green (light grey) bars show decrease in parent-adolescent conflict, red (dark grey) bars show increase in parent-adolescent conflict. Right panel: over time changes in parent-adolescent conflict. Green (light grey) lines show decrease in parent-adolescent conflict. Red (dark grey) lines show increase in parent-adolescent conflict. All models with a significant variance of S2 are displayed in Figure S1). 
Supplemental Materials for

\title{
Parenting Adolescents in Times of a Pandemic: Changes in Relationship Quality, Autonomy
}

\section{Support, and Parental Control?}

Anne Bülow ${ }^{1,2, a}$ (bulow@essb.eur.nl), Loes Keijsers ${ }^{1,}$ a (keijsers@essb.eur.nl), Savannah Boele ${ }^{1,2}$ (s.boele@essb.eur.nl), Eeske van Roekel² (g.h.vanroekel@uvt.nl), \& Jaap J. A. Denissen³

$$
\text { (j.j.a.denissen@uu.nl) }
$$

${ }^{1}$ Department of Psychology, Education \& Child Studies/Clinical Child and Family Studies, Erasmus

\author{
University Rotterdam, \\ ${ }^{2}$ Department of Developmental Psychology, Tilburg University, \\ ${ }^{3}$ Department of Developmental Psychology, Utrecht University
}

${ }^{\text {a }}$ Both contributed equally

\begin{abstract}
Author Note
The preregistered analytical plan syntaxes and data are shared on OSF (https://osf.io/bavf9/).

Funding. This research was supported by a grant from the Netherlands Organization for Scientific Research (NWO; 452-17-011) awarded to Dr. Loes Keijsers.

Acknowledgements. We are grateful for the participating families, and the support of Claire Laudijvan Koot, David Harris and Sander Vermeulen in collecting these data.
\end{abstract}




\section{Paired T-tests}

\section{Table S1}

\begin{tabular}{cllllll}
\hline Variable & Diff ${ }^{a}$ & $t$ & $d f$ & $p$ & $d$ & $95 \%$ CI \\
\hline Warmth & & & & & & \\
LD-4 & 0.01 & 0.29 & 133 & .769 & 0.03 & {$[-0.09,0.12]$} \\
LD-3 & 0.09 & 1.81 & 128 & .072 & 0.18 & {$[-0.01,0.18]$} \\
LD-2 & 0.02 & 0.35 & 132 & .729 & 0.04 & {$[-0.88,0.13]$} \\
LD-1 & 0.02 & 0.33 & 117 & .741 & 0.03 & {$[-0.08,0.12]$} \\
LD+1 & -0.04 & -0.71 & 106 & .478 & -0.09 & {$[-0.17,0.08]$} \\
LD+2 & 0.04 & 0.65 & 106 & .520 & 0.08 & {$[-0.09,0.17]$} \\
LD+3 & 0.02 & 0.36 & 93 & .718 & 0.05 & {$[-0.10,0.14]$} \\
LD+4 & 0.02 & 0.38 & 114 & .705 & 0.04 & {$[-0.08,0.12]$} \\
Conflict & & & & & & \\
LD-4 & -0.09 & -1.24 & 133 & .218 & -0.12 & {$[-0.23,0.05]$} \\
LD-3 & -0.25 & -3.49 & 128 & $<.001$ & -0.36 & {$[-0.40,-0.11]$} \\
LD-2 & -0.19 & -2.82 & 132 & .010 & -0.26 & {$[-0.32,-0.06]$} \\
LD-1 & -0.08 & -1.14 & 117 & .258 & -0.10 & {$[-1.14,0.06]$} \\
LD+1 & -0.12 & -1.40 & 106 & .165 & -0.16 & {$[-0.28,0.05]$} \\
LD+2 & -0.19 & -2.61 & 105 & .010 & -0.24 & {$[-0.33,-0.05]$} \\
LD+3 & -0.08 & -1.04 & 93 & .300 & -0.11 & {$[-0.24,0.07]$} \\
LD+4 & -0.10 & -1.49 & 114 & .138 & -0.15 & {$[-0.24,0.03]$}
\end{tabular}

Autonomy

support

$\begin{array}{lllllll}\text { LD-4 } & -0.14 & -1.93 & 133 & .056 & -0.23 & {[-0.28,0.00]} \\ \text { LD-3 } & -0.05 & -0.83 & 128 & .408 & -0.08 & {[-0.18,0.08]} \\ \text { LD-2 } & -0.02 & -0.35 & 132 & .724 & -0.04 & {[-0.15,0.72]} \\ \text { LD-1 } & -0.06 & -0.86 & 117 & .391 & -0.11 & {[-0.21,0.08]} \\ \text { LD+1 } & 0.04 & 0.49 & 106 & .627 & 0.06 & {[-0.13,0.21]} \\ \text { LD+2 } & 0.02 & 0.24 & 106 & .810 & 0.03 & {[-0.17,0.22]} \\ \text { LD+3 } & -0.09 & -1.08 & 93 & .283 & -0.14 & {[-0.26,0.08]} \\ \text { LD+4 } & -0.05 & -0.73 & 114 & .466 & -0.08 & {[-0.19,0.09]}\end{array}$

Psychological control

$\begin{array}{lllllll}\text { LD-4 } & 0.14 & 2.92 & 133 & .004 & 0.32 & {[0.05,0.24]} \\ \text { LD-3 } & 0.10 & 2.02 & 128 & .046 & 0.22 & {[0.00,0.20]} \\ \text { LD-2 } & 0.14 & 2.77 & 132 & .006 & 0.29 & {[0.04,0.24]} \\ \text { LD-1 } & 0.09 & 1.59 & 117 & .114 & 0.20 & {[-0.02,0.20]} \\ \text { LD+1 } & 0.10 & 1.83 & 106 & .069 & 0.22 & {[-0.01,0.20]} \\ \text { LD+2 } & 0.06 & 1.11 & 105 & .268 & 0.13 & {[-0.05,0.18]} \\ \text { LD+3 } & 0.14 & 2.33 & 93 & .022 & 0.29 & {[0.02,0.27]} \\ \text { LD+4 } & 0.08 & 1.42 & 114 & .159 & 0.16 & {[-0.03,0.20]}\end{array}$

Behavioral control

$\begin{array}{lllllll}\text { LD-4 } & 0.49 & 3.48 & 133 & <.001 & 0.40 & {[0.21,0.77]} \\ \text { LD-3 } & 0.46 & 3.44 & 128 & <.001 & 0.39 & {[0.20,0.73]} \\ \text { LD-2 } & 0.55 & 4.23 & 132 & <.001 & 0.47 & {[0.29,0.81]} \\ \text { LD-1 } & 0.47 & 3.26 & 117 & .001 & 0.38 & {[0.18,0.75]} \\ \text { LD+1 } & 0.23 & 1.53 & 107 & .129 & 0.19 & {[-0.07,0.53]} \\ \text { LD+2 } & 0.26 & 1.50 & 105 & .127 & 0.20 & {[-0.08,0.61]} \\ \text { LD+3 } & 0.49 & 2.63 & 93 & .010 & 0.37 & {[0.12,0.87]} \\ \text { LD+4 } & 0.36 & 2.28 & 114 & .025 & 0.27 & {[0.05,0.66]}\end{array}$

Note. ${ }^{\mathrm{a}}$ Mean of Differences (Adolescent - Parent). A positive value represents a higher value in the adolescent report. $\mathrm{LD}=$ lockdown. 


\section{Sensitivity Analysis}

\section{Table S2}

Model Results with Variances Restricted $>0$

\begin{tabular}{|c|c|c|c|c|c|c|}
\hline \multirow[b]{2}{*}{$\begin{array}{c}\text { Measure } \\
\text { (Respondent) }\end{array}$} & \multirow[b]{2}{*}{ Growth factors } & \multicolumn{4}{|c|}{ Estimates } & \multirow{2}{*}{$\begin{array}{l}\text { Model fit } \\
\text { RMSEA } \\
\text { CFI } \\
\text { TLI }\end{array}$} \\
\hline & & $M$ & $S E$ & Variance & $S E$ & \\
\hline \multirow[t]{4}{*}{ Conflict (A) } & L1 (adjustment) & $1.75 * * *$ & 0.05 & $0.35 * * *$ & 0.05 & .09 \\
\hline & S1 (development) & -0.01 & 0.02 & 0.00 & 0.01 & .97 \\
\hline & $\begin{array}{l}\text { L2 } \\
\text { (disequilibrium) }\end{array}$ & 0.10 & 0.06 & $-0.03^{a}$ & 0.09 & .96 \\
\hline & S2 (adaptation) & 0.00 & 0.02 & 0.01 & 0.01 & \\
\hline \multirow{4}{*}{$\begin{array}{l}\text { Conflict (A) - } \\
\text { Sensitivity }\end{array}$} & L1 (adjustment) & $1.75 * * *$ & 0.05 & 0.35 & 0.05 & .09 \\
\hline & S1 (development) & -0.01 & 0.02 & 0.00 & 0.00 & .97 \\
\hline & $\begin{array}{l}\text { L2 } \\
\text { (disequilibrium) }\end{array}$ & 0.10 & 0.06 & 0.00 & 0.00 & .96 \\
\hline & S2 (adaptation) & 0,00 & 0.02 & 0.01 & 0.01 & \\
\hline \multirow{4}{*}{$\begin{array}{l}\text { Psychological } \\
\text { control (P) }\end{array}$} & L1 (adjustment) & $1.20 * * *$ & 0.03 & $0.07 * * *$ & 0.02 & .00 \\
\hline & S1 (development) & 0.00 & 0.01 & 0.02 & 0.00 & 1.00 \\
\hline & $\begin{array}{l}\text { L2 } \\
\text { (disequilibrium) }\end{array}$ & 0.00 & 0.03 & $-0.01^{\mathrm{a}}$ & 0.04 & 1.04 \\
\hline & S2 (adaptation) & $<0.02$ & 0.01 & 0.00 & 0.00 & \\
\hline \multirow{4}{*}{$\begin{array}{l}\text { Psychological } \\
\text { control (P) - } \\
\text { Sensitivity }\end{array}$} & L1 (adjustment) & $1.20 * * *$ & 0.03 & 0.07 & 0.01 & .00 \\
\hline & S1 (development) & 0.00 & 0.01 & 0.00 & 0.00 & 1.00 \\
\hline & $\begin{array}{l}\text { L2 } \\
\text { (disequilibrium) }\end{array}$ & -0.00 & 0.03 & 0.00 & 0.00 & 1.04 \\
\hline & S2 (adaptation & 0.00 & 0.01 & 0.00 & 0.00 & \\
\hline
\end{tabular}

Note. Variances were tested one-sided, as they cannot $<0 . M=$ mean. $S E=$ standard error. $\mathrm{A}=$ adolescent, $\mathrm{P}=$ parent.

${ }^{a}$ Heywood cases (variance $<0$ ), for these cases sensitivity tests were conducted. The result pattern did not change. L1 (level 1 or intercept) reflects overall levels of adjustment. S1 (Slope 1) reflects developmental change over the course of the whole study. L2 (level 2 or intercept) reflects the increase or decrease in mean level during lockdown, controlling for L1 and S1. S2 (slope 2) reflects changes during LD that cannot be explained by S1 (nor by L1 and S1), and is interpreted as adaptation.

$* p<.05 . * * p<.01 . * * * p<.001$. 


\section{Table S3}

Model Comparison with Intercept only model according to Widaman and Thompson (2003)

\begin{tabular}{|c|c|c|c|c|c|c|c|c|c|c|c|c|c|}
\hline \multirow{2}{*}{$\begin{array}{l}\text { Measure } \\
\text { (Respondent) }\end{array}$} & \multicolumn{4}{|c|}{ Intercept only model } & \multicolumn{4}{|c|}{ Piece-wise model } & \multicolumn{3}{|c|}{ Model Comparison } & \multicolumn{2}{|c|}{ Adjusted fit } \\
\hline & $\chi^{2}$ & $d f$ & $C F I^{a}$ & $T L I^{a}$ & $\chi^{2}$ & $d f$ & $C F I^{a}$ & $T L I^{a}$ & $\chi^{2}$ & $d f$ & $p$ & $C F I^{b}$ & $T L I^{b}$ \\
\hline $\begin{array}{l}\text { Parental Warmth } \\
\text { (A) }\end{array}$ & 78.25 & 34 & 0.97 & 0.97 & 29.62 & 22 & 0.99 & 0.99 & 48.62 & 12 & $<.001$ & 0.83 & 0.73 \\
\hline $\begin{array}{l}\text { Parent-Adolescent } \\
\text { Conflict (A) }\end{array}$ & 135.32 & 34 & 0.89 & 0.91 & 53.42 & 22 & 0.96 & 0.96 & 81.90 & 12 & $<.001$ & 0.69 & 0.52 \\
\hline $\begin{array}{l}\text { Autonomy } \\
\text { Support(A) }\end{array}$ & 92.76 & 34 & 0.93 & 0.94 & 28.28 & 22 & 0.99 & 0.99 & 64.48 & 12 & $<.001$ & 0.89 & 0.83 \\
\hline $\begin{array}{l}\text { Psychological } \\
\text { Control (A) }\end{array}$ & 46.61 & 19 & 0.83 & 0.86 & 46.61 & 19 & 0.83 & 0.86 & & & & & \\
\hline $\begin{array}{l}\text { Behavioral } \\
\text { Control (A) }\end{array}$ & 154.24 & 34 & 0.89 & 0.91 & 46.84 & 22 & 0.98 & 0.97 & 107.41 & 12 & $<.001$ & 0.79 & 0.68 \\
\hline $\begin{array}{l}\text { Parental Warmth } \\
\text { (P) }\end{array}$ & 70.02 & 34 & 0.96 & 0.97 & 31.64 & 22 & 0.99 & 0.99 & 38.38 & 12 & $<.001$ & 0.73 & 0.59 \\
\hline $\begin{array}{l}\text { Parent-Adolescent } \\
\text { Conflict (P) }\end{array}$ & 96.17 & 34 & 0.94 & 0.95 & 40.22 & 22 & 0.98 & 0.98 & 55.94 & 12 & $<.001$ & 0.71 & 0.55 \\
\hline $\begin{array}{l}\text { Autonomy } \\
\text { Support(P) }\end{array}$ & 159.62 & 34 & 0.79 & 0.82 & 50.72 & 22 & 0.95 & 0.94 & 108.90 & 12 & $<.001$ & 0.77 & 0.65 \\
\hline $\begin{array}{l}\text { Psychological } \\
\text { Control (P) }\end{array}$ & 40.62 & 34 & 0.98 & 0.98 & 11.58 & 22 & 1 & 1.04 & 30.82 & 12 & $.002^{\mathrm{d}}$ & & \\
\hline $\begin{array}{l}\text { Behavioral } \\
\text { Control }(\mathrm{P})\end{array}$ & 97.80 & 34 & 0.94 & 0.95 & 26.73 & 22 & 0.99 & 0.99 & 71.07 & 12 & $<.001$ & 0.93 & 0.89 \\
\hline
\end{tabular}

Note. Intercept-only models: Model with one global intercept (L1), Piece-wise models: models for main analysis, see Table 7 in manuscript. ${ }^{a}$ Model fit indices according to Mplus(Muthén \& Muthén, 2017). ${ }^{\mathrm{b}}$ Model fit indices calculated according to Widaman \& Thompson (2003) by comparing the intercept-only model with the piece-wise models. ${ }^{c}$ No comparison could be calculated as the piecewise model was respecified (due to a unsatisfactory fit) to an intercept-only model and is thus identical to the model it should be compared to. ${ }^{\mathrm{d}}$ Satorra-Bentler Scaled Chi-Square Difference Test was employed to account for MLR. 


\section{Covariance Matrices}

\section{Table S4}

Covariance Matrix of Parental Warmth from Adolescent-Reported Data

\begin{tabular}{lcccccccc}
\hline & 1 & 2 & 3 & 4 & 5 & 6 & 7 & 8 \\
\hline 1. Warmth LD-4 & 0.29 & & & & & & \\
2. Warmth LD-3 & 0.22 & 0.26 & & & & & \\
3. Warmth LD-2 & 0.23 & 0.22 & 0.29 & & & & & \\
4. Warmth LD-1 & 0.22 & 0.22 & 0.24 & 0.29 & & & & \\
5. Warmth LD+1 & 0.22 & 0.22 & 0.22 & 0.24 & 0.29 & & \\
6. Warmth LD+2 & 0.23 & 0.20 & 0.23 & 0.24 & 0.24 & 0.33 & \\
7. Warmth LD+3 & 0.20 & 0.19 & 0.23 & 0.23 & 0.24 & 0.23 & 0.29 & \\
8. Warmth LD+4 & 0.20 & 0.20 & 0.22 & 0.24 & 0.23 & 0.22 & 0.23
\end{tabular}

Note. $\mathrm{LD}=$ lockdown. Variance of measures is presented on the diagonal.

\section{Table S5}

Covariance Matrix of Parental Warmth from Parent-Reported Data

\begin{tabular}{lcccccccc}
\hline & 1 & 2 & 3 & 4 & 5 & 6 & 7 & 8 \\
\hline 1. Warmth LD-4 & 0.16 & & & & & & \\
2. Warmth LD-3 & 0.13 & 0.20 & & & & & & \\
3. Warmth LD-2 & 0.13 & 0.15 & 0.22 & & & & & \\
4. Warmth LD-1 & 0.12 & 0.14 & 0.15 & 0.18 & & & & \\
5. Warmth LD+1 & 0.12 & 0.14 & 0.16 & 0.14 & 0.22 & & \\
6. Warmth LD+2 & 0.13 & 0.15 & 0.17 & 0.15 & 0.16 & 0.23 & & \\
7. Warmth LD+3 & 0.13 & 0.15 & 0.15 & 0.14 & 0.16 & 0.17 & 0.20 \\
8. Warmth LD+4 & 0.11 & 0.13 & 0.13 & 0.13 & 0.14 & 0.15 & 0.16 \\
\hline
\end{tabular}

Note. $\mathrm{LD}=$ lockdown. Variance of measures is presented on the diagonal. 


\section{Table S6}

Covariance Matrix of Parent-Adolescent Conflict from Adolescent-Reported Data

\begin{tabular}{lcccccccc}
\hline & 1 & 2 & 3 & 4 & 5 & 6 & 7 & 8 \\
\hline 1. Conflict LD-4 & 0.58 & & & & & & & \\
2. Conflict LD-3 & 0.35 & 0.45 & & & & & & \\
3. Conflict LD-2 & 0.39 & 0.34 & 0.48 & & & & & \\
4. Conflict LD-1 & 0.36 & 0.34 & 0.36 & 0.58 & & & & \\
5. Conflict LD+1 & 0.37 & 0.34 & 0.38 & 0.41 & 0.54 & & \\
6. Conflict LD+2 & 0.40 & 0.31 & 0.36 & 0.45 & 0.44 & 0.66 & & \\
7. Conflict LD+3 & 0.35 & 0.26 & 0.32 & 0.36 & 0.41 & 0.48 & 0.55 \\
8. Conflict LD+4 & 0.33 & 0.26 & 0.30 & 0.39 & 0.40 & 0.44 & 0.50 \\
\hline
\end{tabular}

Note. $\mathrm{LD}=$ lockdown. Variance of measures is presented on the diagonal.

\section{Table S7}

Covariance Matrix of Parent-Adolescent Conflict from Parent-Reported Data

\begin{tabular}{lcccccccc}
\hline & 1 & 2 & 3 & 4 & 5 & 6 & 7 & 8 \\
\hline 1. Conflict LD-4 & 0.53 & & & & & & & \\
2. Conflict LD-3 & 0.38 & 0.54 & & & & & & \\
3. Conflict LD-2 & 0.42 & 0.43 & 0.57 & & & & & \\
4. Conflict LD-1 & 0.39 & 0.44 & 0.46 & 0.50 & & & & \\
5. Conflict LD+1 & 0.37 & 0.38 & 0.42 & 0.39 & 0.53 & & \\
6. Conflict LD+2 & 0.39 & 0.37 & 0.40 & 0.40 & 0.41 & 0.54 & & \\
7. Conflict LD+3 & 0.39 & 0.33 & 0.39 & 0.37 & 0.37 & 0.41 & 0.51 \\
8. Conflict LD+4 & 0.33 & 0.33 & 0.33 & 0.33 & 0.34 & 0.36 & 0.37 \\
\hline
\end{tabular}

Note. LD = lockdown. Variance of measures is presented on the diagonal. 


\section{Table S8}

Covariance Matrix of Autonomy Support from Adolescent-Reported Data

\begin{tabular}{lcccccccc}
\hline & 1 & 2 & 3 & 4 & 5 & 6 & 7 & 8 \\
\hline 1. AuSup LD-4 & 0.47 & & & & & & & \\
2. AuSup LD-3 & 0.33 & 0.49 & & & & & & \\
3. AuSup LD-2 & 0.29 & 0.30 & 0.42 & & & & & \\
4. AuSup LD-1 & 0.29 & 0.30 & 0.30 & 0.42 & & & & \\
5. AuSup LD+1 & 0.29 & 0.29 & 0.30 & 0.28 & 0.46 & & \\
6. AuSup LD+2 & 0.29 & 0.25 & 0.31 & 0.30 & 0.41 & 0.59 & & \\
7. AuSup LD+3 & 0.25 & 0.23 & 0.29 & 0.26 & 0.33 & 0.39 & 0.56 \\
8. AuSup LD+4 & 0.29 & 0.31 & 0.31 & 0.27 & 0.28 & 0.32 & 0.33 & 0.48 \\
\hline
\end{tabular}

Note. AuSup = autonomy support. $\mathrm{LD}=$ lockdown. Variance of measures is presented on the diagonal.

\section{Table S9}

Covariance Matrix of Autonomy Support from Parent-Reported Data

\begin{tabular}{|c|c|c|c|c|c|c|c|c|}
\hline & 1 & 2 & 3 & 4 & 5 & 6 & 7 & 8 \\
\hline 1. AuSup LD-4 & 0.23 & & & & & & & \\
\hline 2. AuSup LD-3 & 0.16 & 0.26 & & & & & & \\
\hline 3. AuSup LD-2 & 0.14 & 0.18 & 0.28 & & & & & \\
\hline 4. AuSup LD-1 & 0.13 & 0.15 & 0.15 & 0.26 & & & & \\
\hline 5. AuSup LD+1 & 0.16 & 0.15 & 0.22 & 0.18 & 0.45 & & & \\
\hline 6. AuSup LD+2 & 0.14 & 0.16 & 0.16 & 0.15 & 0.26 & 0.42 & & \\
\hline 7. AuSup LD+3 & 0.13 & 0.16 & 0.17 & 0.13 & 0.22 & 0.30 & 0.34 & \\
\hline 8. AuSup LD+4 & 0.11 & 0.14 & 0.15 & 0.12 & 0.18 & 0.23 & 0.21 & 0.28 \\
\hline
\end{tabular}

Note. AuSup = autonomy support. $\mathrm{LD}=$ lockdown. Variance of measures is presented on the diagonal. 


\section{Table S10}

Covariance Matrix of Psychological Control from Adolescent-Reported Data

\begin{tabular}{lcccccccc}
\hline & 1 & 2 & 3 & 4 & 5 & 6 & 7 & 8 \\
\hline 1. PCont LD-4 & 0.34 & & & & & & & \\
2. PCont LD-3 & 0.18 & 0.26 & & & & & & \\
3. PCont LD-2 & 0.16 & 0.22 & 0.31 & & & & & \\
4. PCont LD-1 & 0.14 & 0.19 & 0.22 & 0.31 & & & \\
5. PCont LD+1 & 0.15 & 0.17 & 0.19 & 0.19 & 0.25 & & \\
6. PCont LD+2 & 0.94 & 0.22 & 0.23 & 0.28 & 0.23 & 0.35 & \\
7. PCont LD+3 & 0.14 & 0.25 & 0.29 & 0.21 & 0.21 & 0.28 & 0.45 \\
8. PCont LD+4 & 0.19 & 0.16 & 0.18 & 0.19 & 0.16 & 0.23 & 0.23 & 0.35 \\
\hline
\end{tabular}

Note. PCont $=$ psychological control. $\mathrm{LD}=$ lockdown. Variance of measures is presented on the diagonal.

\section{Table S11}

Covariance Matrix of Psychological Control from Parent-Reported Data

\begin{tabular}{lcccccccc}
\hline & 1 & 2 & 3 & 4 & 5 & 6 & 7 & 8 \\
\hline 1. PCont LD-4 & 0.12 & & & & & & & \\
2. PCont LD-3 & 0.09 & 0.12 & & & & & & \\
3. PCont LD-2 & 0.09 & 0.08 & 0.14 & & & & & \\
4. PCont LD-1 & 0.07 & 0.07 & 0.07 & 0.11 & & & \\
5. PCont LD+1 & 0.08 & 0.08 & 0.09 & 0.08 & 0.15 & & \\
6. PCont LD+2 & 0.07 & 0.07 & 0.09 & 0.08 & 0.10 & 0.13 & \\
7. PCont LD+3 & 0.06 & 0.06 & 0.08 & 0.07 & 0.08 & 0.09 & 0.12 \\
8. PCont LD+4 & 0.07 & 0.07 & 0.09 & 0.08 & 0.10 & 0.11 & 0.10 \\
\hline
\end{tabular}

Note. PCont $=$ psychological control. $\mathrm{LD}=$ lockdown. Variance of measures is presented on the diagonal. 
Table S12

Covariance Matrix of Behavioral Control from Adolescent-Reported Data

\begin{tabular}{lcccccccc}
\hline & 1 & 2 & 3 & 4 & 5 & 6 & 7 & 8 \\
\hline 1. BCont LD-4 & 1.88 & & & & & & & \\
2. BCont LD-3 & 1.26 & 1.58 & & & & & & \\
3. BCont LD-2 & 1.46 & 1.18 & 1.75 & & & & & \\
4. BCont LD-1 & 1.39 & 1.06 & 1.35 & 1.76 & & & \\
5. BCont LD+1 & 1.31 & 1.08 & 1.40 & 1.33 & 1.89 & & \\
6. BCont LD+2 & 1.83 & 1.02 & 1.34 & 1.35 & 1.48 & 2.19 & \\
7. BCont LD+3 & 1.31 & 1.14 & 1.35 & 1.40 & 1.60 & 1.79 & 2.33 \\
8. BCont LD+4 & 1.26 & 1.15 & 1.27 & 1.46 & 1.55 & 1.73 & 1.96 & 2.16 \\
\hline
\end{tabular}

Note. BCont $=$ behavioral control. $\mathrm{LD}=$ lockdown. Variance of measures is presented on the diagonal.

\section{Table S13}

Covariance Matrix of Behavioral Control from Parent-Reported Data

\begin{tabular}{|c|c|c|c|c|c|c|c|c|}
\hline & 1 & 2 & 3 & 4 & 5 & 6 & 7 & 8 \\
\hline 1. BCont LD-4 & 1.11 & & & & & & & \\
\hline 2. BCont LD-3 & 0.87 & 1.06 & & & & & & \\
\hline 3. BCont LD-2 & 0.85 & 0.83 & 1.06 & & & & & \\
\hline 4. BCont LD-1 & 0.89 & 0.94 & 0.91 & 1.32 & & & & \\
\hline 5. BCont $\mathrm{LD}+1$ & 0.87 & 0.87 & 0.77 & 0.98 & 1.39 & & & \\
\hline 6. BCont $\mathrm{LD}+2$ & 0.87 & 0.89 & 0.78 & 1.00 & 1.05 & 1.35 & & \\
\hline 7. BCont LD+3 & 0.89 & 0.88 & 0.79 & 0.99 & 1.06 & 1.11 & 1.29 & \\
\hline 8. BCont LD +4 & 0.87 & 0.84 & 0.78 & 0.92 & 0.99 & 1.08 & 1.06 & 1.23 \\
\hline
\end{tabular}

Note. BCont = behavioral control. $\mathrm{LD}=$ lockdown. Variance of measures is presented on the diagonal. 


\section{Moderators}

\section{Table S14}

Moderators of Parental Warmth

\begin{tabular}{|c|c|c|c|c|}
\hline & \multicolumn{2}{|c|}{ Adolescent-report } & \multicolumn{2}{|c|}{ Parent-report } \\
\hline & $\begin{array}{l}\text { Level } \\
(\mathrm{L} 2)^{\mathrm{a}}\end{array}$ & $\begin{array}{l}\text { Change } \\
(\mathrm{S} 2)\end{array}$ & Level (L2) & $\begin{array}{l}\text { Change } \\
(\mathrm{S} 2)^{\mathrm{a}}\end{array}$ \\
\hline Mean level before COVID-19 (L1) & $-.23 * *$ & $-.53 * * *$ & -.07 & $-.50 * * *$ \\
\hline Disequilibrium (L2) & & $.26 * * *(.16)$ & & $.52 * * *(.55 * * *)$ \\
\hline Trait-level parental anxiety $(\mathrm{P})$ & $-.02(-.06)$ & $.13(.04)$ & $.02(.00)$ & $.15(-.03)$ \\
\hline Parental worry about COVID-19 (P) & $-.11(-.13)$ & $.11(.08)$ & $-.02(-.03)$ & $.01(-.09)$ \\
\hline Opp. Defiance (A) & $.04(-.04)$ & $.24 * *(.12)$ & $.06(.00)$ & $.29 * *(.10)$ \\
\hline Opp. Defiance (P) & $.04(-.01)$ & $.09(-.05)$ & $.09(.07)$ & $.43^{* * *}\left(.26^{* *}\right)$ \\
\hline Legitimacy beliefs (A) & $-.04(.01)$ & $-.12(-.02)$ & $.08(.11)$ & $-.14(-.05)$ \\
\hline Child age (A) & $-.08(-.11)$ & $.06(-.001)$ & $.03(.02)$ & $.02(-.02)$ \\
\hline Child gender (A) & $.06(.01)$ & $.09(-.03)$ & $-.06(-.07)$ & $.07(.01)$ \\
\hline Child education level (A) & $-.01(-.04)$ & $.12(.06)$ & $.01(.01)$ & $-.03(-.01)$ \\
\hline
\end{tabular}

Note. Partial correlation controlling for Mean level before COVID-19 in brackets. $\mathrm{A}=$ adolescent. $\mathrm{P}=$ parent. Opp. Defiance $=$ oppositional defiance.

${ }^{a}$ significant variance of growth factor.

$* p<.05 .{ }^{* *} p<.01 . * * * p<.001$. 


\section{Table S15}

Moderators of Parent-Adolescent Conflict

Adolescent-report

Level (L2) Change

$(\mathrm{S} 2)$

Mean level before COVID-19 (L1)

Disequilibrium (L2)

Trait-level parental anxiety $(\mathrm{P})$

$.15(-.01) \quad-.05(.05)$

Parental worry about COVID-19 (P) $\quad-.01(-.16) \quad-.04(.01)$

$.29 * * *$

$-.10(.01)$

Opp. Defiance (P)

Legitimacy beliefs (A)

Child age (A)

Child gender (A)

Child education level (A)

$$
.19 *(.10) \quad-.001(.08)
$$

$-.11(-.02) \quad .11(.07)$

$.12(.02) \quad-.16 *(-.11)$

$.02(.02) \quad .04(.06)$

$.09(.02)$

$.03(.09)$
$-.03(.13)$

$-.14(.05)$

$-.05(-.08) \quad .06(.05)$

$.07(.04)$

$.04(-.01)$

$.14(.15)$

$.05(.04)$

$.05(.02)$
$(\mathrm{S} 2)^{\mathrm{a}}$ $-.58 * * *$

$.74 * * *$

$(.65 * * *)$

$-.17(-.11)$

$.01(.07)$

$.10(.04)$

Note. Partial correlation controlling for Mean level before COVID-19 in brackets. $\mathrm{A}=$ adolescent. $\mathrm{P}=$ parent. Opp. Defiance $=$ oppositional defiance.

${ }^{a}$ significant variance of growth factor.

$* p<.05 . * * p<.01 . * * * p<.001$. 


\section{Table S16}

Moderators of Autonomy Support

\begin{tabular}{|c|c|c|c|c|}
\hline & \multicolumn{2}{|c|}{ Adolescent-report } & \multicolumn{2}{|l|}{ Parent-report } \\
\hline & $\begin{array}{l}\text { Level } \\
(\mathrm{L} 2)^{\mathrm{a}}\end{array}$ & $\begin{array}{l}\text { Change } \\
(\mathrm{S} 2)^{\mathrm{a}}\end{array}$ & Level (L2) & $\begin{array}{l}\text { Change } \\
\text { (S2) }\end{array}$ \\
\hline Mean level before COVID-19 (L1) & .06 & -.02 & $.35 * * *$ & $-.64 * * *$ \\
\hline Disequilibrium (L2) & & $\begin{array}{l}-.69^{* * *}(- \\
.69 * * *)\end{array}$ & & $\begin{array}{l}-.36^{* * *}(- \\
\left..19^{*}\right)\end{array}$ \\
\hline Trait-level parental anxiety $(\mathrm{P})$ & $-.16(-.15)$ & $.04(.04)$ & $-.17(-.08)$ & $.09(-.11)$ \\
\hline Parental worry about COVID-19 (P) & $-.14(-.13)$ & $-.02(-.02)$ & $-.10(-.06)$ & $.08(.005)$ \\
\hline Opp. Defiance (A) & $.03(.04)$ & $-.08(-.09)$ & $-.23 *(-.16)$ & $.17(.02)$ \\
\hline Opp. Defiance (P) & $.06(.07)$ & $-.08(-.09)$ & $\begin{array}{l}-.28 * *(- \\
.20 *)\end{array}$ & $.12(-.08)$ \\
\hline Legitimacy beliefs (A) & $-.07(-.07)$ & $.03(.03)$ & $.11(.08)$ & $-.08(-.02)$ \\
\hline Child age (A) & $-.08(-.08)$ & $.06(.06)$ & $.14(.04)$ & $-.25 * *(-.08)$ \\
\hline Child gender (A) & $.09(.10)$ & $-.15(-.15)$ & $-.02(.03)$ & $.15(.07)$ \\
\hline Child education level (A) & $-.09(-.09)$ & $.01(.004)$ & $<.001(-.06)$ & $-.15(-.05)$ \\
\hline
\end{tabular}

Partial correlation controlling for Mean level before COVID-19 in brackets. $\mathrm{A}=$ adolescent. $\mathrm{P}=$ parent.

Opp. Defiance $=$ oppositional defiance.

${ }^{a}$ significant variance of growth factor.

$* p<.05 . * * p<.01 . * * * p<.001$. 


\section{Table S17}

Moderators of Psychological Control

\begin{tabular}{lllll}
\multicolumn{2}{l}{ Adolescent-report } & & \multicolumn{2}{l}{ Parent-report } \\
\cline { 1 - 1 } Level & Change & & Level (L2) & Change \\
$(\mathrm{L} 2)$ & $(\mathrm{S} 2)$ & & $(\mathrm{S} 2)$
\end{tabular}

Mean level before COVID-19 (L1)

$.37 * * * \quad .22 * *$

Disequilibrium (L2)

Trait-level parental anxiety $(\mathrm{P})$

$.18^{*}(.14) \quad .15(.13)$

Parental worry about COVID-19 (P)

$.04(.06) \quad .08(.09)$

Opp. Defiance (A)

$-.02(-.09) \quad-.10(-.14)$

Opp. Defiance (P)

$.15(.11) \quad .01(-.02)$

Legitimacy beliefs (A)

$.23 *$

$28 * *(.31 * * *)$

$(.28 * *)$

Child age (A)

$-.02(-.02) \quad-.06(-.05)$

Child gender (A)

$-.09(-.10) \quad-.04(-.04)$

Child education level (A)

$-.05(-.06) \quad .04(.03)$

Note. Partial correlation controlling for Mean level before COVID-19 in brackets. $\mathrm{A}=$ adolescent. $\mathrm{P}=$ parent. Opp. Defiance $=$ oppositional defiance.

${ }^{a}$ significant variance of growth factor.

${ }^{*} p<.05 .{ }^{* *} p<.01 .{ }^{* * *} p<.001$. 


\section{Table S18}

Moderators of Behavioral Control

\begin{tabular}{|c|c|c|c|c|}
\hline & \multicolumn{2}{|c|}{ Adolescent-report } & \multicolumn{2}{|c|}{ Parent-report } \\
\hline & $\begin{array}{l}\text { Level } \\
\text { (L2) }\end{array}$ & $\begin{array}{l}\text { Change } \\
\text { (S2) }\end{array}$ & $\begin{array}{l}\text { Level } \\
(\mathrm{L} 2)^{\mathrm{a}}\end{array}$ & $\begin{array}{l}\text { Change } \\
\text { (S2) }\end{array}$ \\
\hline Mean level before COVID-19 (L1) & $.78 * * *$ & $-.35 * * *$ & -.14 & $-.36 * * *$ \\
\hline Disequilibrium (L2) & & $\begin{array}{l}-.15(- \\
.71 * * *)\end{array}$ & & $.64^{* * *}\left(.64^{* * *}\right)$ \\
\hline Trait-level parental anxiety $(\mathrm{P})$ & $\begin{array}{l}-.07(- \\
.12)\end{array}$ & $.17(.11)$ & $.07(.09)$ & $.00(.05)$ \\
\hline Parental worry about COVID-19 (P) & $\begin{array}{l}-.01(- \\
.04)\end{array}$ & $.06(.06)$ & $.12(.12)$ & $.08(.09)$ \\
\hline Opp. Defiance (A) & $.03(.03)$ & $.05(.05)$ & $.03(.07)$ & $-.03(.05)$ \\
\hline Opp. Defiance (P) & $.10(-.01)$ & $.08(.04)$ & $.04(.07)$ & $-.01(.09)$ \\
\hline Legitimacy beliefs (A) & $\begin{array}{l}-.03(- \\
.04)\end{array}$ & $-.02(-.01)$ & $.10(.08)$ & $.12(.06)$ \\
\hline Child age (A) & $-.02(.05)$ & $-.03(-.01)$ & $.07(.04)$ & $.08(.00)$ \\
\hline Child gender (A) & $.00(.06)$ & $-.11(-.10)$ & $-.05(-.04)$ & $.06(.10)$ \\
\hline Child education level (A) & $-.10(.01)$ & $-.00(.05)$ & $-.10(-.13)$ & $-.07(-.16)$ \\
\hline
\end{tabular}

Note. Partial correlation controlling for Mean level before COVID-19 in brackets. $\mathrm{A}=$ adolescent. $\mathrm{P}=$ parent. Opp. Defiance $=$ oppositional defiance.

${ }^{\text {a }}$ significant variance of growth factor.

$* p<.05 . * * p<.01 . * * * p<.001$. 


\section{Visualization of Hypotheses 2}

\section{Figure S1}

\section{Change in Relationship Dimensions}
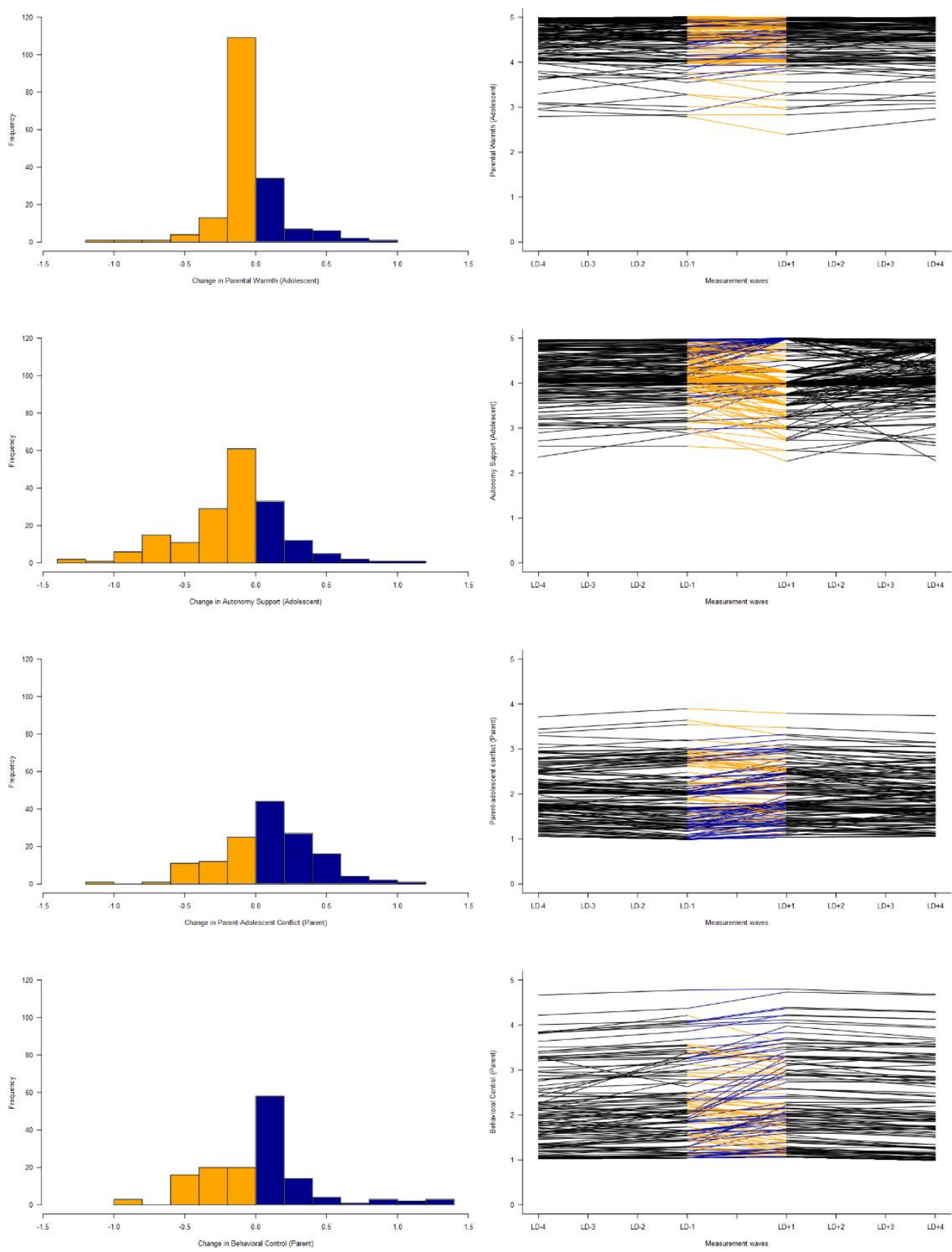

Note. Significant variation in change in relationship dimensions are visualized in two ways. Left panels:

distribution of change parameter L2 during lockdown. Yellow (light grey) bars show decrease in relationship dimension, blue (dark grey) bars show increase in relationship dimenssion. Right panels: over time changes relationship dimensions. Yellos (light grey) lines show decrease in relationship dimension. Blue (dark grey) lines show increase in relationship dimension. 


\section{6 instruments}

\section{Parental support}

\section{Questionnaire:}

Original response scale:

Adapted response scale:

\section{Informant(s):}

Adolescent-version
Network of Relationships Inventory (NRI; Furman \& Buhrmester, 1985)

1 (Little to none) - 2 (A little) - 3 (Much) - 4 (Very much) - 5 (The most)

1 (Not at all) -2 (Little to none) -3 (A little) -4 (Much) -5 (Very much)

Adolescent and parent

In the last two weeks ..

1. How much did your parent admire and respect you?

Hoeveel bewonderde en respecteerde je moeder / vader / stiefmoeder / stiefvader je?

2. How much did your parent care about you?

Hoeveel gaf je moeder / vader / stiefmoeder / stiefvader om je?

3. How much did your parent appreciate the things you did?

Hoeveel waardeerde je moeder / vader / stiefmoeder / stiefvader de dingen die je had gedaan?

4. How much did you care about your parent?

Hoeveel gaf jij om je moeder / vader / stiefmoeder / stiefvader?

Parent-version

In the last two weeks ..

1. How much did you admire and respect your child?

Hoeveel bewonderde en respecteerde $u$ uw kind?

2. How much did you care about your child?

Hoeveel gaf u om uw kind?

3. How much did you appreciate the things your child did?

Hoeveel waardeerde u de dingen die uw kind had gedaan?

4. How much did you care about your child?

Hoeveel gaf uw kind om u?

5. How confident were you that the relationship with your child will last no matter what? Hoe zeker was u ervan dat de relatie met uw kind zal blijven bestaan, wat er ook gebeurt? 


\section{Parent-child conflict}

Questionnaire:

Orginial response scale:

Adapted response scale:

Informant(s):

Adolescent-version

In the last two weeks ..

1. How often did you and your parent annoy and get mad with each other?

Hoe vaak ergerden jij en je moeder / vader / stiefmoeder / stiefvader je aan elkaar en werden jullie boos op elkaar?

2. How often did you and your parent argue and fight with each other?

Hoe vaak zaten jij en je moeder / vader / stiefmoeder / stiefvader met elkaar te bekvechten en ruzie te maken?

3. How often did you and your parent nag one another?

Hoe vaak zaten jij en je moeder / vader / stiefmoeder / stiefvader elkaar dwars?

Parent-child version

In the last two weeks ..

1. How often did you and your child annoy and get mad with each other?

Hoe vaak ergerden uw kind en u zich aan elkaar en werden jullie boos op elkaar?

2. How often did you and your child argue and fight with each other?

Hoe vaak zaten u en uw kind met elkaar te bekvechten en ruzie te maken?

3. How often did you and your child nag one another?

Hoe vaak zaten u en uw kind elkaar dwars? 


\section{Autonomy support}

Questionnaire:

Original response scale:

Adapted response scale:

Informant(s):

Adolescent-version

In the last two weeks ..

1. My parent let me make my own plans for things I wanted to do

Mijn moeder/vader liet me mijn eigen plannen maken voor wat ik wilde doen

2. My parent allowed me to choose what to do, whenever possible

Mijn moeder/vader liet mij zelf kiezen wat ik kon gaan doen, wanneer mogelijk

3. My parent allowed me to decide things for myself

Mijn moeder/vader liet toe dat ik dingen zelf besliste

4. My parent allowed me to choose my own direction in life

Mijn moeder/vader liet me zelf mijn richting in het leven bepalen

Parent-version

In the last two weeks I allowed my child to..

1. Make his or her own plans for things he/she wanted to do

Zijn/haar eigen plannen maken voor wat hij/zij wilde doen

2. choose what he/she wanted to do, whenever possible

Zelf kiezen wat hij/zij kon gaan doen, wanneer mogelijk

3. decide things for themselves

Dingen zelf beslissen

4. To choose his or her own direction in life

Zijn/haar richting in het leven kiezen 


\section{Parental psychological control/disrespect}

\section{Questionnaire: Psychological Control-Disrespect Scale (Barber et al., 2012)}

Original response scale: $\quad 1$ (Not like her/him), 2 (Somewhat like her/him), 3 (A lot like her/him)

Adapted response scale: 1 (Never) -2 (almost never) -3 (sometimes) -4 (often) -5 (always)

Informant(s):

Adolescent and parents

Adolescent-version

In the last two weeks ..

1. My parent ridiculed my or put my down (e.g., saying I am stupid, useless, etc.)

Mijn ouders hadden mij belachelijk gemaakt of mij naar beneden gehaald (bijv. zeggen dat ik dom was of nutteloos)

2. My parents embarrassed me in public (e.g., in front of my friends)

Mijn ouders brachten mij in verlegenheid waar anderen bij waren (bijv. waar mijn vrienden bij waren)

3. My parents did not respect me as a person (e.g., not letting me talk, favoring others over me, etc.) Mijn ouders hadden geen respect voor mij (bijv. door mij niet te laten uitpraten, anderen voortrekken)

4. My parents tried to make me feel guilty for something I've done or something s/he thinks I should do

Mijn ouders probeerden mij schuldig te laten voelen voor iets wat ik niet gedaan had of waarvan hij/zij dacht dat ik het beter kon doen

Parent-version

In the last two weeks ..

1. I ridiculed or put my down my child (e.g., saying I am stupid, useless, etc.) Heb ik mijn kind belachelijk gemaakt of mijn kind naar beneden gehaald

2. I embarrassed my child in public (e.g., in front of my friends) Heb ik mijn kind in verlegenheid gebracht waar anderen bij waren

3. I did not respect my child as a person (e.g., not letting me talk, favoring others over me, etc.) Had ik geen respect voor mijn kind

4. I tried to make my child feel guilty for something he/she did or something I though he/she could do better

Heb ik geprobeerd mijn kind schuldig te laten voelen voor iets wat hij/zij niet gedaan had of waarvan ik dacht dat mijn kind het beter kon doen 


\section{Behavioral control}

Questionnaire:

Response scale:

Informant(s):

Adolescent-version

In the last two weeks ..

1. Did your parents require you to tell them how you spent your money? Eisten je ouders dat je hun vertelde hoe je je geld had besteed?

2. Did your parents demand you to tell where you were going, with whom and what you were going to do?

Eisten je ouders dat je vertelde waar je heenging, met wie en wat jullie gingen doen?

3. Before you left on the weekend, did your parents demand you to tell them where you were going and with whom?

Eisten je ouders voordat je weg ging in het weekend dat je hun vertelde waar je naartoe ging en met wie?

Parent-version

1. Did you require your child to tell you how he/she spent his/her money?

Eiste u je kind te vertellen hoe hij/zijn zijn/haar geld had besteed?

2. Did you demand your child to tell where he/she was going, with whom and what they were going to do?

Eiste $u$ uw kind te vertellen waar hij/zij heenging, met wie en wat ze gingen doen?

3. Did you demand your child before he/she left on the weekend, to tell you where he/she was going and with whom?

Eiste $u$ uw kind in het weekend te vertellen waar hij/zij naartoe ging en met wie voordat uw kind wegging? 


\section{Time with parents and peers}
Questionnaire: Self-made
Response scale: $\quad$ Slider from 0 to 24 hours
Informant(s): Adolescent and parents
Note:
spending time with friends was not asked to the parents

Adolescent-version

1. How many hours per day do you typically spend with these persons on a weekday?

- parent 1 (e.g., mother)

- Parent 2 (e.g., father)

- Friends

2. How many hours per day do you typically spend with these persons on a weekend day?

- parent 1 (e.g., mother)

- Parent 2 (e.g., father)

- Friends

3. How many hours per day do you now spend with these persons on a weekday? (now = the past few days that the coronavirus is spreading)

- parent 1 (e.g., mother)

- Parent 2 (e.g., father)

- Friends

4. How many hours per day do you now spend with these persons on a weekend day? (now $=$ the past few days that the coronavirus is spreading)

- parent 1 (e.g., mother)

- Parent 2 (e.g., father)

- Friends

5. How many hours per day do you typically speak to your friends online or by phone?

6 . How many hours per day do you now speak to your friends online or by phone?

Parent-version

1. How many hours per day do you typically spend with your child on a weekday?

2. How many hours per day do you typically spend with your child on a weekend day?

3. How many hours per day do you now spend with your child on a weekday? (now $=$ the past few days that the coronavirus is spreading)

4. How many hours per day do you now spend with your child on a weekend day? (now $=$ the past few days that the coronavirus is spreading) 


\section{Corona-related rules}

Questionnaire: Self-made

Response scale: $\quad$ open (3 rows)

Informant(s): Adolescent and parents

Note:

spending time with friends was not asked to the parents

Did your parents install new rules because of the new situation with COVID-19? Briefly describe these new parental rules shortly. [adolescent-version]

Did you give your child new rules because of the new situation with COVID-19? Briefly describe new parental rules shortly. [parent-version] 


\section{Oppositional defiance}

Questionnaire: Oppositional defiance (Vansteenkiste \& Soenens, \& Duriez, 2014)

Response scale: 1 (not at all true) -2 (rather not true) -3 (sometimes true and sometimes not true) -4 (rather true) -5 (completely true)

Informant(s): $\quad$ Adolescent and parents

When answering these questions, think about the new rules that your parents installed because of the coronavirus.

Last week ...

1. I did the opposite of what my parents expect from me

Heb ik juist het omgekeerde gedaan van wat mijn ouders verwachten van mij.

2. I completely ignored the rules of my parents

Legde ik de regels van mijn ouders helemaal naast mij neer.

3. I rebelled against my parents' rules

Rebelleerde ik tegen de regels van mijn ouders

4. I did not care about the rules of my parents: I did what I wanted to do

Had ik geen boodschap aan de regels van mijn ouders: ik deed waar ik zelf zin in had

When answering these questions, think about the new rules that you installed because of the coronavirus.

Last week ...

1. My child did the opposite of what was expected from him/her

Deed uw kind juist het omgekeerde van wat hem of haar verwacht werd.

2. My child completely ignored the rules of their parents

Mijn kind legde ik de regels van ouders helemaal naast zich neer.

3. My child rebelled against the rules of their parents

Rebelleerde uw kind tegen de regels van ouders

4. My child did not care about the rules of their parents: He or she did what he or she wanted to do

Had uw kind geen boodschap aan de regels van mijn ouders: hij of zij deed waar hij of zij zin in had 


\section{Legitimacy beliefs of parental authority about corona-related rules}

Questionnaire: Legitimacy beliefs of parental authority (based on Smetana \& Asquith, 1994)

Response scale: $\quad 1$ (fully disagree) -2 (somewhat agree) -3 (fully agree)

Notes:

Translated by Savannah Boele

Informant(s): Adolescent

Given the corona-virus pandemic, it is okay that my parents installed rules about ..

1. .. how I spend my free time wat ik doe in mijn vrije tijd

2. .. what I can or cannot do with friends wat ik wel en niet mag doen met vrienden

3. .. how I spend my day Hoe ik mijn dag indeel

4. .. what I do for school Hoeveel I doe voor school

5. .. going outside Naar buiten mogen gaan

6. .. eat healthier Gezonder eten

7. .. my personal hygiene Mijn persoonlijke verzorging

8. .. how much I should sport or exercise Hoeveel ik moet sporten/bewegen

9. .. spending time with family Het zien van familie (buiten het gezin)

10. .. how much distance I should keep to other people Hoeveel afstand $i k$ moet houden t.o.v. andere mensen 


\section{Anxiety symptoms of parent}

\section{Questionnaire: $\quad$ State-trait Anxiety Inventory Short (STAI; Marteau \& Bekker, 1992)}

Total nr. of items: $\quad 6$ (STAI) and 1 self-made item about worrying about COVID-19

Response scale: 1 (not at all) -2 (somewhat) -3 (moderately) -4 (very much)

Informant(s): Parent

A number of statements which people have used to describe themselves are given below. Read each statement and then circle the most appropriate number to the right of the statement to indicate how you feel right now, at this moment. There are no right or wrong answers. Do not spend too much time on any one statement but give the answer which seems to describe your present feelings best.

1. I feel calm

Ik voel me kalm

2. I am tense

Ik ben gespannen

3. I feel upset

Ik ben van streek

4. I am relaxed

$I k$ voel me relaxed

5. I feel content

Ik ben tevreden

6. I am worried

Ik ben bezorgd

7. I worried about the coronavirus

Maakte ik mij zorgen over het coronavirus 